\title{
AÇÃO COLETIVA, CULTURA E SOCIEDADE CIVIL* Secularização, atualização, inversão, revisão e deslocamento do modelo clássico dos movimentos sociais***
}

\author{
Jeffrey C. Alexander
}

O termo movimentos sociais diz respeito aos processos não institucionalizados e aos grupos que os desencadeiam, às lutas políticas, às organizações e discursos dos líderes e seguidores que se formaram com a finalidade de mudar, de modo freqüentemente radical, a distribuição vigente das recompensas e sanções sociais, as formas de interação individual e os grandes ideais culturais.

\section{O modelo clássico}

Na história da teoria e da ciência social ocidental, as mais importantes abordagens desses processos seguiram um quadro de referências estabelecido pela interpretação histórica das revoluções. Os movimentos sociais foram identificados segundo o modelo dos movimentos revolucionários, entendidos como mobilizações de massa que visam apossar-se do poder de um Estado antagônico. De acordo com essa concepção, o objetivo dos
O sociólogo [...] deve procurar compreender as condições de existência, autonomia e desenvolvimento da sociedade civil em outras palavras, as relações sociais, os conflitos e os processos politicos que tecem a trama da vida social e deve ser capaz de reconhecer suas formas ocultas, deterioradas e reprimidas. (Touraine, 1983a, pp. 233-234). revolucionários é substituir uma forma opressora de poder estatal por outra voltada para um fim distinto, mas que se utiliza de meios semelhantes.

O modelo clássico de interpretação dos movimentos sociais é fortemente impregnado de materialismo ontológico e realismo epistemológico, ênfases derivadas da noção de senso comum das raízes práticas da mudança radical que se desenvolveu nos últimos três séculos, e de uma especial inflexão conferida a esse empirismo filosófico pela emergência da sociedade industrial. Os intelectuais responsáveis pela organização e pelo conteúdo ideológico dos movimentos revolucionários geralmente os concebiam de maneira instrumental, isto é, como o meio mais eficiente para alcançar a distribuição radical dos bens. Aceitavam como uma inevitabilidade histórica o fato de que essas lutas dependiam da coerção e da violência. De acordo com Sartre, a Revolução Francesa começou com um ataque violento e sangrento à Bastilha; segundo Trotski, a revolução russa culminou com o assalto ao Palácio de 
Inverno. O êxito dessas duas insurreições envolveu batalhas campais e, durante os meses e anos posteriores ao triunfo revolucionário, os novos dirigentes recorreram a todos os meios possíveis, inclusive a violência e a repressão, para impedir que os inimigos, os antigos governantes, retomassem o poder.

Deve-se a Alain Touraine a elaboração dessa reconstrução histórica dos movimentos sociais "clássicos" e do seu quadro teórico. "Os velhos movimentos sociais", escreveu Touraine, "foram associados à idéia de revolução", e esta associação deu origem a uma clara orientação tática para o poder, a violência e o controle. "A questão fundamental era o controle do poder, e imagens mais simbólicas incluíam a violência: a ocupação da Bastilha ou do Palácio de Inverno, manifestações de massa freqüentemente dissolvidas violentamente pela polícia, ocupações de fábricas e greve geral" (Touraine, 1992a, p. 143). Essas táticas foram por sua vez associadas a uma ênfase estratégica no "papel central dos arranjos institucionais, da divisão do trabalho e das formas de organização econômica" (Touraine, 1985, p. 280). No entanto, Touraine (1984, p. 38) salienta que essas táticas e estratégias refletiam menos uma realidade social inevitável do que" o pensamento social materialista que norteou a concepção ocidental da sociedade desde o século XVIII". Como o materialismo criou "as representações arquitetônicas da vida social", os movimentos sociais do século XIX identificaram" nos recursos tecnológicos e econômicos" os "alicerces de um edifício [...] constituído por formas de organização social e política" (Touraine, 1984, p. 38).

Em um sentido empírico, os movimentos revolucionários não deixavam de ter efetivamente uma forma cultural ou um conteúdo ético. $\mathrm{Na}$ realidade, as referências teóricas acessíveis aos seus líderes é que limitaram sua autoconsciência. Os líderes revolucionários concebiam seus movimentos como meios instrumentais cuja eficácia dependia do uso da coerção e da força. Ideais e aspectos práticos pareciam-lhes totalmente interligados, saber e poder eram uma coisa só. Touraine (1977, p. 323) chamou a atenção para uma "confusão" intelectual que restringiu o foco dos atores revolucionários ao campo da economia. A "garantia metassocial" desses primeiros movimentos, acredita Touraine, foi definida pelo "modelo cultural" gerado pela" sociedade industrial", que aparentemente sugeria que qualquer mudança social significativa teria de "coincidir com o campo das relações econômicas". Em conseqüência disso, a narrativa revolucionária declarou que só depois do estabelecimento de novas formas de estrutura, somente depois que as transformações técnicas permitissem a redistribuição eqüitativa de bens e serviços, é que considerações de ordem ética, moral e cultural seriam levadas em conta.

Karl Marx, o primeiro e mais importante ideólogo de um movimento revolucionário do século XIX, contribuiu mais do que qualquer outro contemporâneo para firmar o prestígio do modelo clássico ao elaborar uma narrativa meta-histórica que deu ênfase aos interesses econômicos e materiais e colocou em segundo plano a reflexão moral e a solidariedade, como questões a ser consideradas em um momento histórico posterior. Pode-se demonstrar que, em vez de a realidade social ter sido o fator determinante do desprezo da subjetividade dos movimentos sociais, o quadro de referências materialista nasceu de alterações no modelo teórico aplicado pelo próprio Marx. Antes de criar a figura do líder revolucionário cujas ações são ditadas pela lógica da sociedade industrial, Marx defendia a opinião exatamente oposta, concordando com o pensamento dos" jovens hegelianos" de que os atores revolucionários teriam de passar por uma transformação emocional, moral e estética antes de que outras mudanças estruturais e objetivas pudessem ocorrer. Desde seus Manuscritos econômicos e filosóficos, Marx insistiu que a propriedade privada só poderia ser abolida se a alienação a base subjetiva da objetificação fosse eliminada primeiro: "A superação da propriedade privada significa, portanto, a completa emancipação de todos os atributos e sentidos humanos [...] tanto de um ponto de vista subjetivo quanto objetivo." (Marx, 1963 [1844], p. 160).

Somente depois que Marx absorveu integralmente a lógica teórica da economia política é que essa visão da revolução se modificou. Só então Marx começou a desenvolver uma teoria dos movimentos sociais revolucionários que excluía 
os aspectos imaginários e normativos. Adotando a postura do positivismo científico, Marx convenceu-se de que toda explicação verdadeiramente empírica da luta dos trabalhadores, bem como toda liderança eficaz em um sentido prático, teria de abandonar o humanismo e a subjetividade: não se devia permitir que idéias e sentimentos sobre uma futura sociedade utópica interferissem na luta pela transformação da sociedade atual. Em vez de argumentar do ponto de vista da subjetividade emancipada, Marx passou a fazê-lo a partir do preceito da ação" alienada" e da ordem externa. Em A sagrada família (Marx, 1967 [1845], p. 368), escreveu que "não se trata do que este ou aquele proletário, ou mesmo o conjunto do proletariado, imagina ser a meta"; e em $A$ ideologia alemã (Marx, 1970 [1846], pp. 58-59) insistiu em que "o comunismo [...] não é um estado de coisas a ser estabelecido, um ideal ao qual a realidade terá de adaptarse"." É uma questão do que o proletariado é e, por conseguinte, do que ele é compelido historicamente a fazer. Sua meta e sua ação histórica são fixadas de antemão, de modo evidente e irrevogável, por sua própria condição de vida" (Marx, 1967 [1845], p. 368). A partir desta perspectiva Marx distinguiu o socialismo, que agora acreditava representar a primeira etapa "realista" da sociedade póscapitalista, do comunismo, visto como a segunda etapa comprometida com a moral e a ordem normativa (Marx, 1962a [1875]). No socialismo, não haveria mais exploração do trabalho no sentido técnico da venda da força de trabalho e da apropriação da mais-valia , mas, sem dúvida, o próprio caráter instrumental do trabalho, juntamente com a vida material em geral e o controle impessoal do Estado, continuariam a existir. $\mathrm{Na}$ luta revolucionária para construir o socialismo, a força "a parteira da velha ordem prenhe de uma nova sociedade" assumia o primeiro plano (Marx, 1962b [1867], p. 751). Somente no seu prefácio ao terceiro volume de $O$ capital, publicado postumamente, Engels realmente admitiu a possibilidade de que futuras lutas revolucionárias pudessem evitar a violência militar das barricadas. Mas, no próprio ato de afirmá-lo, Engels reconheceu que a força e o poder tinham sido fatores centrais no marxismo original e, de modo mais geral, no pensamento revolucionário do século XIX.

\section{A análise sociológica dos movimentos sociais}

\section{A secularização do modelo clássico}

Da abordagem clássica dos movimentos sociais originaramse os mais influentes quadros de referência teóricos utilizados pelos cientistas sociais, não só do ponto de vista da sociologia dos movimentos revolucionários como do estudo dos movimentos não radicais. $\frac{1}{}$ No que diz respeito aos teóricos contemporâneos dos movimentos sociais, pode-se dizer que eles" secularizaram" o modelo clássico, despojando-o da teleologia revolucionária e conservando sua teoria explicativa firmemente racional, distributiva e materialista. Quer se inspirassem em Marx, Weber, ou nos autores que no pós-guerra adotaram a teoria do conflito, quer fossem influenciados pelos teóricos da escolha racional, individual e coletiva, os mais importantes sociólogos das últimas duas décadas interpretaram os movimentos sociais como respostas práticas e coerentes à distribuição desigual das privações sociais criada pela mudança institucional. Oberschall definiu a questão com toda clareza em Social conflict and social movements (1973), obra que deu início à fase mais recente da secularização. Os sistemas sociais são constituídos por "posições, estratos e classes sociais", escreveu Oberschall, e estes, por sua vez, são configurados pela "combinação da divisão do trabalho com [hierarquias] de subordinação e superioridade". Tudo o mais decorre desses fatos aparentemente simples e mais ou menos imutáveis desde os primórdios da sociedade." Os privilegiados têm interesses precípuos na manutenção e consolidação da parte que lhes cabe nessa divisão; os desfavorecidos buscam aumentar sua respectiva quota, de modo individual ou coletivo. O conflito social resulta do choque desses interesses opostos." (Oberschall, 1973, p. 33). Quando a secularização do modelo clássico convergiu para fenômenos de nível mais micro, ignorou as dimensões morais e afetivas da ação coletiva, enfatizando em seu lugar as limitações decorrentes da existência de redes interligadas e da disponibilidade de organizações. Pensava-se que esses fatores pudessem proporcionar à ação social meios confiáveis e eficazes de mobilizar os recursos necessários 
ao seu êxito. Isso porque organizações eficazes e padrões estruturados de relações sociais podem ser utilizados de modo prático e, dadas essas condições infra-estruturais (Mann, 1986 e 1994), os movimentos não só ganham poder como influência para modificar a distribuição dos bens materiais. Quer sejam de natureza micro ou macrossocial, os movimentos devem ser sempre considerados por uma ótica pragmática.

Assim como os teóricos clássicos encontraram chaves de interpretação na consciência dos intelectuais que lideraram os movimentos operários, os cientistas sociais contemporâneos têm se inspirado no que julgam ser a visão dos líderes dos movimentos sociais mais notáveis de nosso tempo. "No curso de sua militância política", escreveram McCarthy e Zald (1977, p. 1.212) em seu ensaio paradigmático sobre o processo de mobilização de recursos, "os líderes de movimentos" formulam estrategicamente não só táticas como também "princípios gerais"; ambos são definidos com o objetivo de "subjugar ambientes hostis". Os movimentos sociais são exercícios calculistas; visam à "fabricação do descontentamento" a fim de mudar a "infra-estrutura da sociedade". Para serem bemsucedidos, esses incitamentos estratégicos têm de recorrer ao poder. As" organizações" conferem poder por aproximação, pois permitem aos movimentos" concretizar [...] objetivos". Mas as organizações só se tornam poderosas se houver disponibilidade de recursos, e essas condições externas de ação, que escapam ao controle subjetivo, é que determinam a força da organização e, em última análise, seu sucesso. Significado e motivação não estão em questão; "o montante da atividade dirigida para a realização de objetivos é, em linhas gerais, uma função dos recursos controlados por uma organização" (McCarthy e Zald, 1977, p. 1.221). Quando suficientemente poderosa, a organização pode desenvolver "uma fábrica de movimentos sociais", e essa forma de produção em que os benefícios tangíveis superam os custos aumenta muito suas chances de sucesso.

Se na opinião dos analistas macrossociológicos contemporâneos os movimentos sociais assemelham-se a complexas máquinas maximizadoras, não surpreende que tratem a violência e a força unicamente como meios eficientes. Os estudos históricos de Tilly secularizam o modelo clássico exatamente dessa maneira (cf. Cohen e Arato, 1992, pp. 504 ss). Tilly refere-se à violência simplesmente como um recurso político eficaz e mais ou menos rotineiro. "A violência grupal", sugere ele, "costuma nascer de ações coletivas que não são intrinsecamente violentas festividades, assembléias, comícios, greves, manifestações públicas" (Tilly, 1975, p. 46). Principalmente no século XIX e no início do século XX, a violência grupal foi o meio visivelmente mais eficiente de "defender interesses comuns". O uso da violência depende de que as condições sociais externas façam-na vantajosa em termos de custos, isto é, que os atores sociais usem a violência para aumentar a utilidade marginal dos seus atos políticos. Assim, examinando "a mudança das condições favoráveis ao protesto violento nas nações ocidentais", Tilly (1975, p. 3) classifica a violência como um subproduto natural da urbanização e da industrialização. Já que a violência é tão rotineira e racional, ele só pode concluir que "a repressão funciona". Segue-se logicamente que "a imposição de penalidades violentas dano ou confisco de pessoas ou objetos à ação coletiva diminui sua freqüência e intensidade" (Tilly, 1975, p. 285).

O modelo revolucionário em sua forma secularizada não tem como argumentar de outra maneira, apesar da notável incongruência freqüentemente verificada entre esse modelo e o caminho contingente, destemido, utópico e acidentado efetivamente percorrido pelas revoluções vitoriosas. 2 A tentativa de Skocpol de explicar as revoluções sociais acompanha essa mesma linha de interpretação. Ideologias, solidariedades e tipos específicos de regime são irrelevantes do ponto de vista causal; ações violentas, objetivos materiais e esforços decididos para controlar os instrumentos de coerção estatal devem ser tratados como meios para fins que, por sua vez, são, eles próprios, simplesmente meios para outros fins. As ideologias dos movimentos sociais não são especificações de preocupações morais mais gerais, mas estratégias de mobilização de massas. O "materialismo organizacional" de Mann (1994), embora mais pluralista e antideterminista, formula uma abordagem dos movimentos sociais pela via 
de redes de poder que só difere nos resultados, não no tipo de explicação.

Dado esse contexto teórico geral, não deve surpreender muito que a maior parte das pesquisas sociológicas mais importantes sobre o movimento dos direitos civis nos Estados Unidos afirme que o desenvolvimento de organizações fortes "centros de movimento" (Morris, 1984, pp. 40-76) foi a principal causa do seu êxito na mobilização de massas. Fatores subjetivos, como uma liderança carismática (Branch, 1988) ou as aspirações das massas por uma nova vida moral (Eyerman e Jamison, 1991, pp. 120145), são interpretados por estes autores que secularizaram o modelo clássico em termos puramente funcionais, como meios altamente eficientes de mobilizar recursos organizacionais (Morris, 1984, pp. 91-93). A infiltração de temas e rituais religiosos cristãos no movimento dos direitos civis é descrita pelos principais estudiosos dos movimentos sociais como uma estratégia eficaz na motivação da ação política não conformista, associando-a ao status mais legítimo e mais estável da filiação a igrejas (Friedman e McAdam, 1992, p. 163). Desse modo, o idealismo apaixonado e o emocionalismo moral que permeiam os grandes movimentos sociais são reduzidos a estratégias inconscientes e tratados como mecanismos inteligentemente utilizados de" driblar" o problema do free rider (idem, pp. 166-169). São estudados como mercadorias manipuladas pelas organizações para aumentar o poder da organização e conquistar mais apoio material e não-material (McAdam, 1988).

A hegemonia da secularização sociológica do modelo clássico evidencia-se inclusive nas tentativas de introduzir uma abordagem mais cultural. Embora aparentando oferecer, em princípio, uma alternativa a essa substantivação da escolha racional, esses trabalhos resultaram no efeito contrário de deslocar os aspectos simbólicos e utópicos, colocando em seu lugar uma exagerada ênfase nos aspectos práticos. Recentemente, Swidler sugeriu, por exemplo, que os movimentos sociais criam inovações culturais porque são menos dispendiosas do que tentar modificar o papel fundamental dos arranjos institucionais básicos.
As agendas de muitos movimentos sociais giram em torno de recodificações culturais. De fato, como a maioria dos movimentos carece de poder político (e por isso mesmo usam táticas políticas não convencionais), é mais eficiente reformular o mundo pela redefinição dos seus termos do que pelo rearranjo das suas sanções. (Swidler, 1996, p. 9)

Embora admita o conteúdo simbólico das demandas dos movimentos sociais, esses argumentos acabam desarticulando a relação entre a ideologia do movimento e as tradições discursivas preexistentes. Em vez de falar de solidariedades criadas por padrões comuns de representações, por exemplo, essa abordagem reduz a quase nada a autonomia relativa dos padrões simbólicos, mostrando que a cultura do movimento é determinada por condições que lhe são exteriores.

As culturas dos movimentos sociais são modeladas pelas instituições com as quais se defrontam. Tipos diferentes de regime e formas diferentes de repressão geram tipos distintos de movimentos sociais, com diferentes táticas e culturas internas. As instituições dominantes modelam os valores mais profundos do movimento. (Swidler, 1996, p. 11)

Essa instrumentalização da abordagem cultural, sua maneira de tratar os elementos e temas simbólicos como ferramentas (Swidler, 1986) que as organizações podem usar ou abandonar a bel-prazer, demonstra a extraordinária influência que o modelo clássico exerce sobre a Sociologia contemporânea.

\section{A inversão do modelo clássico}

Entretanto, se a secularização do modelo clássico predomina entre os estudos macrossociológicos contemporâneos sobre os movimentos sociais, o papel da subjetividade não passou inteiramente despercebido. $\mathrm{Na}$ última década, uma pequena mas expressiva rede de sociólogos e cientistas políticos americanos, liderada por David Snow e seus colegas (por exemplo, Snow et al., 1986; Snow e Benford, 1988), discutiu sobre a maneira como o entendimento cognitivo e moral das questões exerce um papel importante na produção do descontentamento que alimenta os movimentos sociais. Gamson (1988 e 1992) ocupou-se de temas como identidade coletiva e discurso público; Klandermans (1988 e 1992) tratou da mobilização do consenso; Tarrow (1992 e 1994) analisou o papel das estruturas de ação coletiva nos movimentos sociais radicais. 
Essas reações contra os limites da instrumentalização e descontextualização da abordagem predominante sobre os movimentos sociais recorrem direta e indiretamente às antigas tradições teóricas estabelecidas em paralelo e em resposta às teorias européias que inspiraram o modelo clássico. Sem dúvida, na própria Europa, alternativas ao modelo revolucionário foram em certa época bastante difundidas, e destacavam as dimensões emocionais e irracionais do comportamento de grupo. As especulações instintualistas de Le Bon sobre o comportamento das multidões são o exemplo mais importante, tendo influenciado os estudos de Freud sobre a psicologia dos grupos. O fato de que essa alternativa ao modelo revolucionário não teve repercussão sobre as linhas principais da futura ciência social pode ser explicado tanto por conter uma rejeição da ideologia liberal e democrática quanto por outras objeções de natureza explicativa levantadas na época. Entretanto, a forte ênfase na irracionalidade das motivações subjetivas que caracterizou essa obra efetivamente provocou uma cegueira empírica em relação aos aspectos estratégicos e contingentes, parecendo negar a possibilidade de que os movimentos sociais se orientem por ideais morais universalistas e individualistas. Houve, é claro, importantes figuras da teoria social clássica que, apesar de atentos para os elementos não-racionais, vincularam esses aspectos ao projeto da democracia liberal; mesmo assim, esses autores raramente focalizaram de modo sistemático os movimentos políticos de massa que lutam pela mudança social. Além disso, quando os abordaram, esses autores freqüentemente o fizeram com um tom pejorativo e pessimista. Foi o que aconteceu, por exemplo, com a insistência de Weber em dizer que os movimentos democráticos só teriam condições de vencer por uma via plebiscitária que dependia do carisma demagógico; foi também o caso de Durkheim, que analisou as assembléias públicas e os movimentos de massa segundo o modelo dos rituais primitivos, uma equação que parecia dar uma importância extremamente reduzida à racionalidade e à contingência. Os estudos de Tarde sobre as relações entre a moda, a conversação, a imprensa e a opinião pública representaram um esforço extremamente original de seguir uma direção diferente. Contudo, embora as idéias de Tarde sobre a microssociologia dos movimentos sociais representem uma alternativa mais liberal, democrática e de ênfase cultural ao modelo revolucionário, suas idéias nunca foram incorporadas às tendências que mais tarde vieram a predominar na pesquisa sociológica. $\frac{3}{}$

No mesmo período, nos Estados Unidos, a situação era completamente diferente. O pragmatismo americano deu origem a teorias republicanas e democráticas a respeito dos interesses subjetivos e da identidade moral como alternativas ao modelo mais pessimista das razões instrumentais e dos interesses materiais, de um lado, e às teorias do mercado, de outro. Mesmo nos trabalhos de autores tão pioneiros como Small (por exemplo, Small e Vincent, 1894, pp. 325-326) e Giddings (1896, p. 134), há uma acentuação na ação individual ao lado de outras formas mais institucionais que medeiam entre as solidariedades morais locais e as esferas públicas nacionais. Analistas posteriores deram continuidade ao estudo desses temas, mas enfatizaram a criatividade e a sensibilidade individual de modo explicitamente mais pragmático. Embora Park tenha sido mais influenciado pelo pensamento irracionalista europeu, fez questão de distinguir entre multidões e públicos (por exemplo, Park, 1972 [1904], p. 80). Cooley (1909, p. 150) deu ênfase à comunicação subjetiva, ao "enlargement" e "animation", e Mead (1964) desenvolveu uma filosofia sistemática da interpretação simbólica e da comunicação gestual.

Entretanto, à medida que essa alternativa pragmática ao modelo revolucionário amadurecia, sua relevância para a macrossociologia diminuiu. Por um lado, Lippman (1992) e Dewey (1927), reagindo ao ambiente mais cético da industrialização que se seguiu à Primeira Guerra Mundial, condenaram o declínio da esfera pública, a manipulação da vida política e a erosão da solidariedade moral, temas estes que, no clima instável e ameaçador dos anos 30 e 40, contribuíram para a difusão da teoria européia da sociedade de massas (por exemplo, Lasswell, 1941). Por outro lado, simultaneamente à perda de confiança nas instituições morais e nos movimentos coletivos, apareceram correntes de sociologia pragmática que se abstiveram dessas reflexões 
de nível societário em troca de questões mais individuais e de ordem interativa. Blumer teve, neste sentido, uma importância crucial por traduzir tendências filosóficas mais gerais em modelos de explicação sociológica. A ênfase unilateral, mais micro do que macro, mais ligada ao individual do que ao social, das idéias de Blumer revela-se com clareza em sua declaração de que os movimentos sociais "podem ser entendidos como sociedades em miniatura e, como tal, representam o desenvolvimento de comportamentos coletivos organizados e formalizados a partir do que originalmente era amorfo e indefinido (Blumer, 1951 [1939], p. 214).

A interpretação "emergentista" de Blumer dos movimentos sociais tratou a" organização social", os "valores" e a "estrutura institucional" como "resíduo[s]" (idem, p. 214) de ação, em vez de admitir que esses "resíduos" constituem seu próprio fundamento; desse modo, significou um estreitamento básico das possibilidades explicativas da tradição pragmática. Considerações históricas e comparativas foram abandonadas, a teorização dos efeitos diferenciadores das esferas institucionais foi deixada de lado. No estudo de Turner e Killian (1972), importantes teóricos da tradição do "comportamento coletivo" posterior a Blumer, o tratamento conferido à contingência esclarece detalhes significativos sobre a organização e a construção dos movimentos, a maneira como as tensões se convertem em senso de justiça, a formação de públicos para questões específicas, e a criação de contramovimentos e o uso da cooptação como controle social (cf. Alexander e Colomy, 1988). No entanto, as referências institucionais e culturais desses processos são tomadas como parâmetros, não como variáveis. Por exemplo: como Turner e Killian, em vez de explicarem, pressupõem a existência de garantias constitucionais para as liberdades civis, o mesmo acontecendo, de um modo geral, com a força de uma comunidade civil solidária, definem o público como uma coletividade emergente constituída apenas pela discussão e pelo debate (Turner e Killian, 1972, pp. 179-198).

Embora o prestígio e a influência na disciplina da abordagem da "escola de Chicago" tenham praticamente desaparecido sob o impacto do funcionalismo (por exemplo, Smelser, 1962) e, depois, da teoria da mobilização de recursos, a escola vem ressurgindo nas atuais vertentes interpretativas da teoria do movimento social a que me referi acima. Alguns estudos nessa linha são muito inovadores. Baseando-se nos trabalhos da última fase de Goffman e em sua teoria da análise dos quadros interpretativos (frame analysis), de inspiração semiótica, por exemplo, Snow e seus colaboradores (1986) aprofundam a minuciosa reconstrução das práticas interpretativas que Turner e Killian iniciaram. Em vez de simplesmente falarem de alinhamento de quadro como tal, eles criam um conjunto contínuo de possíveis práticas interpretativas que abrangem desde aquelas que reforçam as regras normativas preexistentes "construção de pontes interpretativas (frame bridging) e "amplificação" até as práticas mais ambiciosas e originais, que denominam de "extensão" e" transformação" . Não obstante seu interesse intrínseco, esses argumentos esmiúçam a dimensão subjetiva dos movimentos sociais de modo puramente microssociológico, muitas vezes tratando as estratégias interpretativas dos seus atores como se fossem geradas de modo totalmente prático, situacional, imediato. 4 A realidade é que, pelo menos nas formas que atualmente se conhecem, o interacionismo constitui mais uma inversão do instrumentalismo e determinismo do modelo clássico do que uma genuína alternativa a ele.

O problema dessas abordagens interacionistas está menos no que incluem do que no que deixam de fora, menos nas afirmações do que nas omissões. Acompanhando Blumer em seu recuo para o "emergentismo", até mesmo as análises interacionistas mais inovadoras dos movimentos sociais aceitam a linguagem institucional e o quadro macrossociológico proposto pelo modelo da mobilização de recursos. Consideram que suas contribuições apontam mais para os "processos de mediação" (Klandermans, 1992, p. 77), subjetivos e comunicativos, do que para as estruturas normativas e institucionais que controlam a própria distribuição dos recursos. Tarrow, por exemplo, aceita integralmente a concepção centrada no Estado e no poder das sociedades contemporâneas formulada por Tilly, apesar de defender uma abertura para a incorporação sistemática da abordagem dos "quadros interpretativos". Tarrow 
conclui a meu ver equivocadamente que as interpretações "ideológicas" e" organizacionais" dos movimentos sociais são mais complementares do que opostas. Os interacionistas tendem a descrever os processos culturais simplesmente como outros tipos de "soluções aos problemas que os movimentos têm de resolver: quais sejam, como preparar, coordenar e sustentar a ação coletiva entre participantes que carecem de recursos mais convencionais e de metas programáticas explícitas" (Tarrow, 1994, p. 7). Este argumento demonstra os mesmos limites da versão cultural da teoria da mobilização de recursos acima discutida: as dimensões criativas e subjetivas dos movimentos sociais são vistas como meios para um fim, não como fins almejados por serem significativos em si mesmos, o que sugere que os próprios movimentos possuem uma meta cultural. .5

Esses limites levam a pensar na clamorosa necessidade de uma abordagem dos movimentos sociais capaz de pôr em xeque o modelo clássico em seus próprios termos, capaz de esclarecer a importância das práticas interpretativas e do meio cultural e que, ao mesmo tempo, mostre como estes aspectos se inter-relacionam com fatores institucionais e históricos (ver também, Sztompka, 1993, pp. 274-300).

\section{A atualização do modelo clássico}

A necessidade de introduzir uma correção ao mesmo tempo histórica e teórica no enfoque clássico para incluir os significados culturais, as identidades psicológicas e uma teorização dos fatores institucionais parece levar diretamente ao estudo dos novos movimentos sociais. Essa importante linha da Sociologia recente, que se originou da Europa mas que hoje é muito difundida nos Estados Unidos, estuda os movimentos sociais partir de uma perspectiva que leva em conta a contingência e a subjetividade dos atores e revela uma forte sensibilidade para os aspectos históricos e institucionais. Ao reconhecer a centralidade da subjetividade nos movimentos sociais contemporâneos, essa perspectiva exige que os analistas ultrapassem os limites de um modelo teórico enraizado no materialismo ontológico e no realismo epistemológico. Ao mesmo tempo, vincula o crescimento da subjetividade às mudanças empíricas ocorridas no plano da macroestrutura, à passagem de uma sociedade industrial para uma sociedade pós-industrial. Considera que as transformações históricas verificadas na produção material tornaram obsoletos os movimentos revolucionários de classe pioneiros; acredita que a centralidade das necessidades materiais e sua epistemologia realista presente no modelo clássico foram deslocadas nos novos movimentos sociais por uma orientação para os significados e as identidades psicológicas. Contudo, conforme sugere o presente resumo do debate, o problema da teoria dos novos movimentos sociais é o exato reverso de sua força. O desafio teórico fundamental ao modelo revolucionário que essa teoria propõe é camuflado e, em última análise, minado por seu historicismo e sua ênfase na primazia dos fatores institucionais na mudança social.

Embora se deva dar a Alain Touraine cuja obra será discutida adiante o crédito de ter formulado pela primeira vez essa perspectiva histórica, as análises mais radicais e categóricas de suas implicações subjetivas e individuais foram feitas por Alberto Melucci. O fundamento lógico da versão inicial da nova abordagem de Melucci (1980, pp. 217-218) segue exatamente o argumento historicista acima descrito. Melucci pergunta: "que mudanças ocorridas no sistema de produção nos permitem falar de novos conflitos de classe?" E sua resposta acompanha muito de perto o modelo clássico: "Os mecanismos de acumulação já não são alimentados pela simples exploração da força de trabalho, mas pela manipulação de complexos sistemas organizacionais, pelo controle da informação e dos processos e instituições formadores de símbolos, ao lado da interferência nas relações pessoais." Em resumo, nas décadas de 60 e 70 surgiu uma nova forma de dominação, pois "o controle e a manipulação dos centros de dominação tecnocrática penetram cada vez mais fundo na vida cotidiana e invadem a liberdade do indivíduo de dispor do seu tempo, seu espaço, suas relações e de ser reconhecido como um indivíduo". Para serem instrumentos eficazes de dominação dessas forças, os movimentos sociais precisam mudar de forma. 
Portanto, o movimento de reapropriação que reivindica o controle sobre os recursos produzidos pela sociedade está levando sua luta a um novo território. A identidade social e pessoal dos indivíduos é cada vez mais percebida como um produto da ação social. [...] A defesa da identidade, continuidade e previsibilidade da existência pessoal começa a constituir a substância do novos conflitos. [...] A identidade pessoal [...] é agora a propriedade que se deseja reivindicar e defender.

Em outras palavras, Melucci reclama que se dê atenção às dimensões subjetivas, afetivas e culturais dos movimentos sociais contemporâneos, mas não entende que essa atenção seja assegurada pela autocrítica teórica dos defensores do modelo clássico, nem em sua forma revolucionária, nem em sua forma secularizada. Na verdade, a necessidade de uma mudança no tratamento teórico e empírico aparece nessas autocríticas como se fosse o resultado das maquinações da história, de uma nova configuração histórica criada pelas condições sociais nascidas exclusivamente das transformações econômicas, e somente no período recente.

Em outras palavras, com a teoria dos novos movimentos sociais, os sociólogos contemporâneos podem ocupar-se da subjetividade sem abandonar uma visão instrumental e materialista das condições que impulsionam esses movimentos e, em última análise, determinam seu êxito. $O$ modo de produção mudou, novos tipos de privações surgiram, e os novos movimentos sociais são o resultado lógico de tudo isso. Sociedades pós-materialistas, pósindustriais, pós-afluentes, baseadas na informação, constituem arranjos estruturais que criam, exatamente nessa ordem, novas formas de estratificação, novos grupos de conflito, novos padrões de dominação e novas percepções dos objetivos e interesses em jogo. Como "no contexto do capitalismo industrial, o modelo da ação coletiva esgotou-se" (Melucci, 1989, p. 246), há necessidade de novos mecanismos que possibilitem a realização da mudança social. Mais do que reivindicar uma redistribuição, os movimentos contemporâneos de protesto concentramse nos códigos, no conhecimento e na linguagem. O conflito baseado na opressão torna-se simbólico, e sua análise requer métodos interpretativos, não somente modelos explicativos.
Conceitos concretos como os de eficácia ou sucesso podem agora ser considerados de pouca importância. Isso porque o conflito se dá principalmente no terreno simbólico, por meio da contestação e da desorganização dos códigos dominantes em função dos quais se estabelecem relações sociais nos sistemas de alta densidade de informação. (Melucci, 1989, p. 248)

A teorização sobre os novos movimentos sociais serviu de ponte legitimadora entre o modelo clássico de movimentos sociais e a compreensão empírica de determinadas tendências inevitáveis na vida social contemporânea. Permitiu manter intacta a antiga estrutura teórica, mudando-se apenas seus referentes empíricos. Será, então, motivo de surpresa que as fraquezas da teoria dos novos movimentos espelhem as deficiências que identificamos no antigo modelo revolucionário? O tratamento é não só teoricamente inadequado como historicamente incorreto. Isso não quer dizer que não haja enormes diferenças entre os movimentos do século XIX e os contemporâneos, mas essas diferenças não dizem respeito ao peso relativo concedido aos fatores objetivos e materiais, em comparação com os subjetivos e culturais.

Cabe assinalar aqui determinados fatos empíricos básicos. Conforme sugeri rapidamente no começo deste ensaio, e desenvolverei mais adiante, desde o final do século XVIII, e até mesmo antes, os movimentos radicais ocorridos nas sociedades da Europa Ocidental e da América do Norte já se orientavam para normas culturais e identidades individuais. Historiadores contemporâneos da Revolução Francesa Furet (1981) e seus colaboradores na França, e historiadores como Hunt (1984 e 1989), Sewell (1980 e 1985) e Baker (1990) nos Estados Unidos deram grande destaque aos fatores culturais nessa insurreição préindustrial prototípica do século XVIII. Esses estudos deixam bem claro que o modelo clássico compreendeu mal a Revolução Francesa, que foi muito menos uma primeira mudança ultra-racional e "moderna" do que uma extensão das velhas idéias republicanas para um contexto histórico novo e sem precedentes, um contexto que estimulou a aplicação na França de uma concepção ultrademocrática do Estado. Da mesma forma, estudos recentes sobre as lutas da classe operária do século XIX (por exemplo, Tucker, 1996) mostram que o modelo clássico distorceu esse 
primeiros movimentos radicais por ignorarem o impacto decisivo sobre os quadros interpretativos das tradições locais e populares (Thompson, 1964) dos reflexos igualitários das idéias democráticas e cristãs (por exemplo, Joyce, 1991) e das versões de classe da ideologia" republicana" que inicialmente se cristalizaram nas sociedades quase-civis das cidades-Estados renascentistas (por exemplo, Montgomery, 1980; Wilentz, 1984).

Não basta atualizar o modelo clássico, assim como não é suficiente secularizá-lo ou invertê-lo. É preciso fazer uma profunda revisão da teoria na sua maneira de entender o que é a mudança social, inclusive nas formas mais radicais.

\section{O deslocamento do modelo clássico}

\section{Importância e ambigïidade de Alain Touraine}

As palavras de Touraine citadas no parágrafo de abertura deste ensaio mostram algumas das suas contribuições fundamentais para a crítica do materialismo e do reducionismo do modelo clássico. De fato, Touraine foi a primeira pessoa a problematizar a própria concepção de "modelo clássico". Ao mesmo tempo, à medida que se dedicava à criação de uma abordagem historicista da mudança social a teoria dos novos movimentos sociais , Touraine preferiu evitar um prolongado confronto com os pressupostos básicos ou teóricos do modelo clássico. Assim, caracterizou sua visão mais subjetiva e centrada no ator dos movimentos sociais como sendo motivada por mudanças empíricas nos objetos de análise, em vez de por alterações teóricas na própria análise. Embora ele se refira pejorativamente ao "modelo revolucionário", afirma que foi o "declínio" histórico da revolução como modalidade de prática, não as deficiências do modelo revolucionário como teoria, que levou os pensadores contemporâneos a conceder "o papel central aos movimentos sociais e não aos arranjos institucionais" (Touraine, 1985, p. 281). Touraine critica o modelo clássico por sua miopia em relação às instituições. Como um marco teórico, escreve ele, o modelo explica "a tendência principal do movimento sindical" apenas em termos "do desejo de assumir o controle do Estado". No entanto, em vez de relacionar essa falha com o aparato conceitual do modelo clássico, Touraine (1983a, p. 232) faz a observação empírica de que "os novos movimentos sociais [estão] muito distantes do modelo revolucionário".

Não quero dizer com esta crítica que Touraine não deu um enquadramento teórico às suas observações sobre a historicidade contemporânea; não se trata disso em absoluto. Enquanto ele trabalhava em sua nova maneira de pensar empiricamente sobre as sociedades contemporâneas, também se empenhava na formulação da "teoria da ação" que costuma ser associada ao seu nome. Gostaria de sugerir, porém, que também nessa teoria (por exemplo, Touraine, 1988), em seus argumentos genéricos sobre a autonomia, subjetividade e reflexividade do ator individual ante os sistemas e instituições sociais, Touraine fundamentou suas afirmações em observações empíricas sobre a natureza mutável das épocas históricas, e essa base historicista torna particularmente vulnerável sua concepção da "ação". A validade da teoria depende da adequação empírica do seu argumento de que os novos movimentos sociais se definem inteiramente por sua ênfase na subjetividade e na individualidade. Sugiro mais adiante que em seus trabalhos recentes Touraine reconhece implicitamente o fracasso deste argumento empírico e que, por conseguinte, a primazia da ação é deslocada.

Todavia, mesmo enquanto Touraine trabalhava em sua concepção da proeminência dos atores ante os sistemas e reclamava para si uma identidade como "teórico da ação", pode-se ver que seu pensamento tomava um rumo muito diferente. De fato, é possível dizer que emerge de seus textos uma espécie de modelo subterrâneo da ação e da ordem dotado de potencialidade para fundamentar uma descrição empírica da sociedade moderna muito diferente do historicismo com o qual ele costuma ser associado na visão do público. Sua profunda imersão nas mentalidades e nos movimentos da década de 60 um comprometimento solidário, engajado, que distingue sua biografia intelectual dentre a de todos os outros autores de teorias gerais sobre a sociedade contemporânea estimulou não só uma nova 
forma de historicismo, que ressalta a contingência e a reflexividade radical, como também uma interpretação mais coletiva e orientada para a sociedade que explicou os movimentos sociais de modo marcadamente cultural. Nessa vertente do seu pensamento, a sociedade pósindustrial é vista como criativa e expressiva, mas também constantemente orientada para uma ordem simbólica totalizadora. Touraine afirma que a ordem normativa geradora do consenso estimula não só a reprodução como a mudança dos padrões vigentes e, na realidade, insiste em dizer que apenas uma orientação para a ordem normativa pode estimular uma mudança social radical.

Nessa dimensão submersa do seu pensamento teórico, Touraine adota certos conceitos sobre os sistemas cultural e social que visam questionar a abordagem estratégica dos movimentos sociais característica do modelo clássico.

Um conceito estratégico da mudança implica necessariamente a redução da sociedade [meramente] a relações entre atores, particularmente relações de poder, desvinculadas de qualquer referência a um sistema social. [Segundo essa concepção] não há interesses em jogo na relação social e não existe nenhum outro campo senão o da própria relação. (Touraine, 1981, p. 56)

Os cientistas sociais devem estar atentos não só às relações entre um movimento social e o poder dominante que busca derrubar, mas também às relações entre esse ator coletivo e o próprio sistema social, relações estas nas quais a dominação é apenas um aspecto. Essas relações sociais mais amplas definem os interesses em jogo no conflito entre os movimentos e o poder. A fim de conceituar essa ordem coletiva externa à política e as relações antiestratégicas que ela inspira, Touraine recorre à idéia de sistema cultural. Alegando que "não pode existir nenhuma relação social a menos que os atores atuem dentro do mesmo campo cultural" (Touraine, 1981, p. 32)," nega categoricamente que uma situação social possa ser reduzida à lógica interna da dominação" (idem, p. 58). E explica que "uma situação social também se baseia numa cultura, isto é, na construção de normas que determinam as relações entre uma comunidade e seu meio, [normas estas] que, em vez de representarem a ideologia do dominador, na realidade definem um campo social" (ibid)." Os atores históricos", conclui Touraine, "são determinados tanto pelo campo da cultura quanto pelo conflito social" (idem, p. 66; cf. Touraine, 1977, pp. 329-330).

Admitindo-se o caráter presuntivo da ênfase de Touraine na dimensão cultural dos movimentos sociais o fato de conter uma hipótese sistêmica e teórica, e não apenas histórica e empírica , pode-se entender de outra maneira sua descrição da sociedade industrial. Quando Touraine e seus colaboradores, François Dubet e Michel Wieviorka, falam da classe operária tradicional do século XIX, interpretam seu economicismo não como uma estratégia voltada para os aspectos materiais, mas como um ato de interpretação coletiva baseado na cultura. Sublinhando os compromissos culturais com o industrialismo que os membros da classe operária compartilhavam com os capitalistas, Touraine e seus colaboradores escrevem que, "além de suportarem a dominação social e cultural, os operários também participam concretamente da cultura industrial e exprimem seus valores" (Touraine et al., 1987, p. 19).

Mais do que um simples modo de produção e alocação de recursos, para fazer uso da terminologia de Parsons e Shils (1951), a sociedade capitalista é caracterizada nesse texto como um modo de integração. A hierarquia de classes subsiste no âmbito da integração cultural mais geral da sociedade industrial, e as lutas pela hegemonia ideológica, não só pelo poder ou pelo dinheiro, caracterizam os conflitos em torno da mudança social. Nas sociedades industriais, os movimentos sociais radicais implicaram muito mais do que uma extensão das organizações e redes, e da mobilização da violência e da força. "No contexto de [sua] participação" na indústria cultural, escrevem Touraine e seus colaboradores (1987, p.19), esses movimentos lutaram" para arrebatar recursos culturais do controle dos industriais e [para] colocá-los à disposição dos operários e de toda a coletividade".

Esse argumento tem profundas conseqüências para as alegações empíricas em que se baseia a teoria historicista da ação, pois sugere que muito antes da sociedade pósindustrial, os movimentos sociais eram lutas que visavam não só à distribuição de recursos materiais, em si e por si 
mesmos, mas conflitos em torno da distribuição de recursos definidos pela cultura e da determinação de qual classe poderia reivindicar o direito normativamente legítimo de distribuir esses recursos para a coletividade. $\mathrm{Na}$ verdade, o conflito de classe só é inteligível, tanto para os seus participantes quanto para seus observadores, porque se dá sobre o pano de fundo de valores consensuais. Embora" seja necessário considerar o movimento operário como um agente social definido [...] por relações conflituosas", ele também se define "por uma referência objetiva, que compartilha com seus adversários, à orientação cultural da sociedade industrial" (Touraine et al., 1987, p. XV).

Touraine esforça-se em demonstrar que essa abordagem se afasta da perspectiva tradicional da esquerda radical. Embora a "sociologia crítica", escreve Touraine (1981, p. 37), "permita-nos fugir da sociologia institucional e evitar seu conformismo, não nos conduz, por si mesma, à sociologia da ação, pois ainda não reconheceu que o comportamento social é orientado por normas". Touraine chama a atenção dos seus colegas intelectuais da esquerda para que não se esqueçam do fato de que as redes institucionais e organizacionais em que os movimentos sociais se implantam são elas mesmas permeadas de interpretações culturais gerais, que costumam ser aceitas sem discussão tanto pelos conservadores quanto pelos radicais. A teoria crítica, adverte Touraine, "não percebe que os atores antagônicos dominadores e dominadosentram em conflito somente porque pertencem ao mesmo campo cultural, porque têm modelos em comum" (Touraine, 1981). $\underline{6}$

Igualmente surpreendente é o fato de Touraine devotar um esforço considerável para demonstrar as semelhanças entre sua nova abordagem e a tradição teórica incontestavelmente não radical do funcionalismo. Chega a ponto de caracterizar seu próprio esforço teórico como uma nova definição do problema parsoniano "da institucionalização". .I Parsons fez uma cuidadosa distinção entre padrões gerais de valores e diretrizes normativas orientadas para ação, derivadas dos primeiros. Afirmou que as normas determinam formas de organização historicamente específicas centradas não nos valores gerais, mas na distribuição de recompensas e sanções. Touraine aceita rigorosamente essa distinção parsoniana, opondo o que chama de "orientações culturais gerais", que impregnam diferentes períodos históricos como a sociedade industrial e a sociedade pós-industrial e formas "normativamente organizadas" de produção e troca. Seguindo o pensamento de Parsons, Touraine insiste em dizer que as últimas se inspiram em orientações culturais gerais, mas não são determinadas por elas. Ao afirmar que a cultura pode ser especificada de diferentes maneiras, Touraine assinala que, se Parsons salientava a diferença entre normas e valores, ele próprio via menos importância nessa distinção. Fundindo as formas de organização social existentes com os ideais culturais que as inspiram, Parsons cometeu o erro idealista de derivar as normas dos valores. Com isso, anulou a tensão entre possibilidade e realidade, que a diferenciação entre a cultura e o sistema social por ele formulada trouxera à luz.

Touraine, ao contrário, insiste em defender a autonomia relativa entre normas e valores. Contra a aplicação reducionista que Parsons fez de sua própria teoria, mostra que somente se a relação entre o sistema social e o sistema cultural for vista de modo bidirecional torna-se possível revelar a verdadeira contingência da história. Por um lado, Touraine repete que os atores são intencionais e reflexivos apenas porque a ação radica em concepções idealistas comuns e fortemente simbólicas. Por outro lado, afirma que os atores só podem criar instituições e relações com os recursos sociais que têm à mão. Essa dualidade demonstra que existe uma grande variedade de soluções institucionais plausíveis e compatíveis com qualquer arcabouço cultural. Em outras palavras, o que Touraine viu e Parsons não entendeu é que a institucionalização é um processo historicamente contingente e de fim indeterminado; depende das idéias, energias e experiências culturais acumuladas das vitórias e das derrotas dos movimentos sociais. "A sociologia da ação deixou de acreditar que o modo de conduzir-se deve ser uma resposta a uma situação; em vez disso, afirma que a situação é simplesmente o resultado mutável e instável das relações entre atores, os 
quais, por intermédio de seus conflitos sociais e orientações culturais, produzem a sociedade" (Touraine,1981, p. 80).

Como Parsons tendia a identificar os arranjos sociais existentes com os valores culturais do sistema, só podia entender os movimentos sociais que contestavam esses arranjos como afastamentos padronizados, ou desvios, dos valores do sistema (cf. Smelser, 1962). Parsons acreditava que as motivações dos atores individuais socializados tendem a ser homólogas não só aos padrões simbólicos, mas também às recompensas e sanções que definem os papéis organizados. O contra-argumento de Touraine assemelha-se à posição energicamente expressa por Parsons e Shils (1951), mas que a tradição funcionalista poucas vezes observou. Parsons e Shils haviam afirmado que se a integração cultural é em si mesma governada pelo requisito de coerência do padrão, exigências de coordenação funcional é que afetam a integração do sistema social. Há um conflito endêmico entre a integração cultural e a integração social, entre os ideais e sua institucionalização, e essa contradição fundamental é que cria os movimentos sociais. Em um determinado ponto, Touraine (1981, pp. 62-63) efetivamente se coloca em claro confronto com Parsons:

Não há nenhuma relação direta entre [...] valores e normas, pois as relações de classe se interpõem entre ambos. [...] Os valores são sempre valores de classe, enquanto as orientações, apesar de dilaceradas pelos conflitos de classe, têm uma existência autônoma. [...] E aí reside a inexpugnável linha divisória que separa a análise aqui formulada e a de Talcott Parsons e sua escola.

Em outras palavras, pode-se dizer que o socialismo igualitário institucionaliza a cultura industrial de modo tão legítimo quanto o sistema hierárquico capitalista, que representa a cultura industrial na forma da propriedade privada. Justamente porque Parsons não compreendeu isto, não foi capaz de atribuir um papel sistemático aos movimentos sociais na sociedade industrial, os quais, na realidade, muitas vezes assumiram um formato socialista. E justamente porque Touraine compreende isto é que, na vertente de sua teoria voltada para o papel da cultura, confere importância aos movimentos sociais radicais que contestam a organização capitalista.
Touraine conseguiu formular, ao mesmo tempo, uma crítica da teoria neomarxista e da teoria funcionalista. Relacionando de modo original e persuasivo cultura e normatividade à luta dos movimentos sociais, lançou as bases para uma ciência social de orientação hermenêutica, mas também crítica, cuja necessidade foi proclamada com tanto vigor por estudiosos das comunidades, como MacIntyre, Walzer e Taylor. Mas a promessa contida no modelo não chegou a se cumprir. Touraine não consegue, ou talvez não queira, traduzir essa perspectiva totalizadora sobre a relação entre ação e ordem, valor e norma, cultura e organização social, em um esquema de explicação empírica aplicável de modo coerente e consistente.

Há uma profunda ambigüidade na concepção de Touraine sobre a natureza das sociedades contemporâneas. Em grande parte, essa ambigüidade é um reflexo das contradições subjacentes aos pressupostos do seu pensamento, mas também se expressa de modo mais imediatamente empírico. Em sua conceituação de sociedade" industrial" e "pós-industrial", Touraine periodiza as sociedades ocidentais e seus valores nucleares segundo o modelo marxista dos modos de produção, abordagem que dá predominância à cultura econômica. No entanto, a "cultura industrial" não chega a esgotar os poderosos sistemas de valores do século XIX. Das esferas da religião, família, gênero, raça, ciência e política também se originaram orientações culturais gerais e de grande influência. Nem todas essas esferas desencadearam movimentos sociais tão poderosos quanto os conflitos de classe; porém, cada uma delas efetivamente gerou padrões de avaliação muito influentes, os quais, por sua vez, deram origem a conflitos institucionais que muitas vezes tiveram conseqüências de enorme importância para os movimentos sociais. Mais sério ainda é o fato de que Touraine negligencia a possibilidade de ter existido no século XIX um arco abrangente de idéias não econômicas, uma mescla de idéias políticas, legais e sociais, que permitiu falar-se na época de uma sociedade civil ou democrática. Na medida em que esse sistema cultural e suas instituições normativas correspondentes estavam em ação, existiu um discurso moral e político impregnado nas esferas mais 
particularmente diferenciadas da sociedade do século XIX, inclusive a industrial, provendo uma importante referência cultural crítica para os movimentos sociais daquele tempo.

Visto dessa maneira, o problema crucial da sociologia dos movimentos sociais de Touraine é saber se a sua reconstrução crítica da teoria da ação toma em consideração uma sociedade civil ampla e fundada na história, que determina continuidades empíricas entre a marcha dos acontecimentos no século XIX e na atualidade. Nos seus trabalhos dos anos 70 e 80 , Touraine resiste muito a aceitar essa possibilidade, apesar de ocasionais insinuações a respeito da existência de certas continuidades. Em um comentário histórico paralelo, por exemplo, Touraine admite em certo momento que a especificidade da história ocidental dependeu do surgimento de uma esfera civil independente: "Durante muito tempo dominado por impérios, o mundo assistiu à abertura de pequenos espaços sociedades civis , primeiro na Europa Ocidental e depois em várias outras regiões do mundo" (Touraine, 1983a, p. 221). Em outro texto, ele chega a relacionar esse fato histórico com a situação política atual, advertindo que "é difícil defender a idéia de que as sociedades ocidentais são tão fechadas, repressivas e autoritárias quanto qualquer outro tipo de sociedade no mundo". E acrescenta: "é impossível substituir a clássica dupla, instituição e socialização, por seu contrário: repressão e reprodução" (Touraine, 1984, p. 36). Na maior parte dos seus escritos, porém, Touraine preferiu acentuar a descontinuidade. Respondendo a uma pergunta que ele mesmo se colocara "Estaremos presenciando ao desaparecimento da sociedade civil?" , escreveu: "Sim, as sociedade civis clássicas estão se desfazendo" (Touraine, 1983a, p. 221).

O problema, neste caso, remete à estreita identidade estabelecida por Touraine entre a cultura do século XIX e os valores da sociedade industrial, pois, acompanhando Marxe a leitura marxista de Hegel , define a sociedade civil como "o espaço social da produção da vida social através do trabalho e da criação por este dos valores culturais" (Touraine, 1992a, p. 134). Em vez de reconhecer a presença de temas fortemente libertários e individualistas nos protestos do século XIX, e seus referentes institucionais pluralistas, Touraine ressalta o coletivismo, o cientificismo e a disciplina desses movimentos, relacionando-os à economia industrial e à organização fabril. Conclui então que somente na fase industrial do capitalismo tornou-se possível disciplinar os indivíduos por meio das obrigações coletivas inerentes aos grandes valores. Com a mudança para uma sociedade pós-industrial da informação, ao contrário," o poder consiste em inventar produtos e padrões com os quais a experiência individual e coletiva pode ser modelada" (Touraine, 1983a, p. 229). Nessa" sociedade em estado de permanente mudança" não sobra nada de consensual, coletivo ou institucional. $\mathrm{O}$ individualismo e a subjetividade reinam soberanos.

A sociedade não tem mais uma natureza, não se baseia mais em qualquer valor ou invariante; é apenas o que faz por si mesma, para melhor ou para pior. É irrelevante ou supérfluo apelar para princípios morais, lei natural, direitos humanos ou valores religiosos a fim de organizar a vida social. A sociedade não é nada senão o produto mutável, instável, frouxamente coerente de relações sociais, inovações culturais e processos políticos. (Touraine, 1983a, p. 220)

As estratégias dos movimentos sociais, ainda que culturais, "já não podem apelar positivamente para as necessidades, os princípios ou a história" (Touraine, 1983a, p. 229). Inspiram-se simplesmente na necessidade de preservarem a si mesmas. A" destruição de [...] estruturas permanentes produzidas pelo imperativo tecnocrático da mudança permanente", sugere Touraine, "induz a um comportamento que visa à defesa da identidade". No entanto, essa identidade "é tão vazia de conteúdo quanto a mudança, que se torna um fim em si mesma" (idem, p. 224).

Nesse vazio criado por sua concepção do colapso da sociedade civil é que se legitima a teoria anti-societária, centrada no ator, de Touraine, e nasce a sua teoria dos novos movimentos sociais. Durante mais de duas décadas de estudos empíricos, Touraine dedicou-se à ambiciosa tarefa de criar uma teoria sistemática das contradições geradas por um sistema econômico pós-industrial mais atrelado à transformação da informação em mercadoria do que aos bens materiais. Por um lado, procurou atualizar, em vez de deslocar, a primazia do modelo de mudança social revolucionária baseado no conflito de classes. Pesquisando 
a enorme e desconcertante variedade de movimentos contemporâneos de protesto, Touraine procurou distinguir os elementos de uma nova classe revolucionária, um grupo cujos membros, por sua posição igualmente subordinada no novo sistema de produção, haveriam de transformar uma resistência difusa à dominação em um movimento social de toda a sociedade capaz de impor uma reestruturação fundamental da sociedade capitalista tardia: "É preciso observar o processo lento, difícil e parcial de formação de um movimento social, compreender como ele se constitui em meio a lutas mais restritas e de sentidos diversos, exatamente como o movimento operário se formou através de greves, lutas políticas, criação de cooperativas e debates de idéias" (Touraine, 1980, p. 41). Ao mesmo tempo, Touraine se diferencia de Marx salientando que este movimento social revolucionário será uma luta pelo controle cultural em vez do controle físico do poder: "Entendemos por movimento social uma luta coletiva iniciada pelos atores de uma classe com a finalidade de obter o controle social das orientações culturais de uma coletividade" (Touraine, 1978, p. 359).

Entretanto, tendo em vista os problemas já assinalados, a questão crucial de Touraine é saber se o arcabouço teórico que ele adotou em seu projeto lhe permitirá compreender a lógica cultural da sociedade contemporânea de uma forma que dê conta de toda e qualquer referência "coletiva", seja de classe, seja de base societária mais ampla. Na fase industrial do capitalismo, a orientação cultural dominante era mais coletiva na forma, enfatizando o materialismo, o crescimento, o progresso e a organização. A passagem para uma sociedade da informação deu origem a uma lógica cultural de relações subjetivas, limites, autenticidade e individualidade.

Esses novos protestos [...] não criticam o uso social do progresso, mas o próprio progresso [...] a defesa do consumidor e mais fundamentalmente do ator cultural. Este significa o indivíduo que procura manter ou recuperar o controle sobre sua própria orientação cultural e seu modo de agir lutando contra as grandes organizações que possuem a capacidade de produzir, difundir e impor linguagens e informações. [Essas organizações] produzem representações da natureza, da realidade social e histórica, do indivíduo, de certas personalidades culturais ou do próprio corpo. (Touraine, 1985, p. 280; cf. Touraine, 1983b, p. 36)
Touraine enxerga nessa lógica cultural contemporânea uma contradição disseminada e fundamental entre as orientações daqueles que controlam as indústrias da informação e daqueles que são dominados por elas. "Os dirigentes das grandes indústrias culturais", escreve Touraine (1992a, p. 141), "falam em nome do individualismo". Mas, ao mesmo tempo em que "falam de criatividade, liberação e liberdade de escolha", constroem "sistemas de saúde, educação e informação destinados a maximizar o 'produto', isto é, a desenvolver no maior grau possível a quantidade de informações médicas, pedagógicas e gerais em circulação". Por oposição, aqueles que são dominados por essa nova classe dirigente estão comprometidos, em virtude de sua posição estrutural, com o individualismo de um modo mais qualitativo e mais radical. "No campo oposto, também se fala em individualismo, liberdade e movimento, mas de modo mais defensivo e mais 'utópico', pois, neste caso, não se fala apenas em nome do indivíduo, mas de sua capacidade e de seu desejo de defender a própria individualidade e subjetividade." (Touraine, 1992a, p. 141).

Em suas intervenções etnográficas nos movimentos de protesto dos estudantes, ecologistas, mulheres e grupos separatistas regionais, Touraine e seus colaboradores afirmaram que cada um deles exprimia de maneira diferente uma subjetividade rebelde. $\underline{8}$ Assim, estudantes e professores compartilhavam um compromisso com uma "universidade livre"; mas enquanto os últimos defendiam "os direitos da ciência" e a "corporação universitária" que a viabiliza, os primeiros definiam a liberdade em termos negativos, como "um espaço e tempo de não-escolha", e por isso podiam" manter-se distantes das condições restritivas do mundo da produção capitalista" (Touraine, 1978 , p. 218). Os movimentos antinucleares começaram falando principalmente da "ameaça geral à vida" e faziam apelos genéricos à liberdade e à condição humana (Touraine, 1983b, p. 31). Contudo, à medida que a" rejeição generalizada de uma ordem cultural e social transformavase sobretudo numa utopia criativa" (idem, p. 9), o movimento logo se "transformou em um confronto com o aparelho tecnocrático tanto mais poderoso quanto 
pertencente ao Estado" (idem, p. 5). Por fim, o movimento "abandonou a idéia de que a sociedade é modelada por tecnologias e descobriu que, ao contrário, a escolha de uma política energética é que é determinada pela modalidade de processo decisório existente na sociedade" (idem, p. 175). Se, no começo, o movimento de mulheres partiu para "uma ruptura com o homem", acabou se transformando" numa luta geral pelo direito a uma relação com o outro", e nesse processo tornou-se "um fator importante do movimento social mais geral de contestação do poder da tecnocracia" (Touraine, 1980, p. 151). À medida que os movimentos separatistas regionais, como os da "Occitanie", exibiam sua parcela de tradicionalismo e romantismo, sua causa era "transformada" num confronto político com "a dominação cada vez mais brutal do centro sobre a periferia" (Touraine e Dubet, 1981, p. 293).

Se essas descrições visam demonstrar que a ideologia de cada protesto específico expressa, à sua maneira, a subjetividade revolucionária de uma nova classe revolucionária, as afirmações sobre "individualidade"," subjetividade", "identidade" e "libertação do controle" dão muito mais a impressão de ser um verniz abstrato de intenção cultural do que reconstruções hermenêuticas. Ao fazer o relato detalhado de protestos específicos, Touraine e seus colaboradores simultaneamente reinterpretaram esses movimentos numa terminologia que não emerge do discurso dos atores, mas de uma teoria preexistente sobre o conflito entre dominadores e dominados numa sociedade pós-industrial. Nessa tradução perde-se a possibilidade de ver se esses atores coletivos perceberam seus interesses ou seus movimentos como estando intrinsecamente ligados à totalidade da sociedade. Seus objetivos são expostos como autônomos e independentes em relação à dominação em si, não como vinculados aos discursos morais da obrigação coletiva. Quando Touraine (1984, p. 38) conclui que "os novos movimentos sociais nos países industrializados opõem a autonomia ao poder, não mais a razão à tradição", deixa claro que sua análise dos movimentos contemporâneos rompeu com uma sólida referência à especificidade das sociedades ocidentais. Os movimentos são apresentados como meros protestos institucionalmente específicos contra a sociedade capitalista tardia, inspirados numa cultura tão subjetiva e individualista que suas várias expressões se tornam apenas meios transparentes através dos quais atores individuais e grupos de interesse se manifestam.

Touraine não abre mão completamente do conceito de sociedade civil; o que faz é transformá-lo numa expressão da "ideologia antiestatal da liberdade" que caracteriza o capitalismo contemporâneo e especifica a diferença entre os novos e os velhos movimentos sociais.

A idéia de sociedade recebe um significado velado: em vez de ser definida por instituições e/ou por um poder central, e levando em conta que certamente não se pode mais defini-la por valores comuns ou regras permanentes de organização social, a sociedade aparenta ser um campo de debates e conflitos em que está em jogo o uso social dos bens simbólicos produzidos em massa por nossa sociedade pós-industrial. (Touraine, 1984, p. 40)

Apesar de admitir que os remanescentes de uma sociedade civil "clássica" dão crescente espaço para o antagonismo com a tecnocracia, Touraine se nega a tratar as ordens institucional e normativa da sociedade civil como forças relativamente autônomas que contribuem para a formação dos movimentos sociais. Afirma, ao invés, que a sociedade civil é que resulta dos movimentos sociais, não o contrário:

Nessas sociedades altamente industrializadas, os conflitos e debates atingem uma determinada unidade de modo autônomo, sem a interferência de um princípio unificador externo [...] A ação de uma tecnocracia dirigente [...] é criar uma tentativa de impor aos cidadãos um determinado tipo de vida social. Uma sociedade mais civil, por outro lado, uma sociedade que seja uma extensão da democracia, é inevitavelmente produto de lutas sociais e processos políticos. (Touraine, 1984, p. 40)

Se os movimentos sociais são bem-sucedidos, Touraine (1983a, p. 229) alega então que o resultado é a formação de uma nova sociedade civil pós-clássica: "Essas lutas podem ampliar a área da atividade política ou criar o que se poderia denominar de nova Öffentlichkeit". Essa nova sociedade civil emerge do próprio vácuo do espaço público da sociedade pós-industrial. Reivindicando o autocontrole e a autogestão em seu próprio nome, os movimentos sociais criam as bases para uma sociedade civil reflexiva, antiessencialista, contingente e totalmente voltada para o ator. Quando Touraine alega que os sociólogos contemporâneos devem 
"procurar compreender as condições de existência, autonomia e desenvolvimento da sociedade civil", identifica essas condições com a busca do entendimento das "relações sociais, conflitos e processos políticos que tecem a trama da sociedade civil" (idem, pp. 233-234). Quanto às estruturas culturais, interacionais e institucionais dessa sociedade civil, ele não tem nada de substantivo a declarar.

A julgar pelos textos mais recentes de Touraine (por exemplo, 1992b e 1994), pode parecer que o programa de teoria e pesquisa descrito nos parágrafos anteriores que se poderia chamar de sociologia do seu "período revolucionário" estaria chegando ao fim. $\mathrm{Na}$ verdade, o que seria surpreendente é se o declínio do espírito revolucionário observado na história recente não tivesse exercido um forte impacto sobre esse intelectual de inclinação essencialmente política. Nos últimos anos (Alexander, 1995), tem havido uma significativa redução do senso da possibilidade social, tanto quanto da viabilidade política e moral, de uma "ruptura" revolucionária (Touraine, 1980, pp. 9-26). Continuar defendendo o argumento de que a revolução cultural suplantou formas mais materialistas seria dedicar-se a analisar o que se transformou em um termo intelectual cada vez mais irrelevante no mundo contemporâneo.

$\mathrm{Na}$ base do programa revolucionário de Touraine (1983b, pp. 140-144) encontra-se o argumento de que, com a emergência da sociedade industrial, a combinação histórica entre democracia, movimentos sociais e revoluções chegou ao fim. Particularmente no século XX, movimentos sociais e democracia "não são apenas diferentes como freqüentemente opostos" (idem, p. 144). Nos seus textos mais recentes, Touraine concentra-se cada vez mais na democracia, e essa declaração sobre o processo de autonomia é diretamente contestada.

Mais do que a criação de uma sociedade política justa ou a abolição de todas as formas de dominação e exploração, o principal objetivo da democracia deve ser permitir que indivíduos, grupos e coletividades se tornem sujeitos livres, produtores de sua história, capazes de reunir em sua ação o universalismo da razão e as particularidades da identidade pessoal e coletiva. (Touraine, 1994, p. 263)
Touraine agora fala da ação coletiva não como um movimento socialmente produzido que deixa à mostra o logro das promessas democráticas, mas como um processo que amplia e aprofunda essas promessas; e refere-se à "condição de livre" e à" liberdade" como temas ao mesmo tempo políticos e morais, não como produtos de uma nova fase da sociedade capitalista.

Uma parte da burguesia inglesa, holandesa, americana e francesa proclamou os princípios gerais da liberdade; depois, o movimento operário reconheceu que essa liberdade teria de ser defendida nas relações concretas de trabalho; nações dependentes ou colonizadas lutaram pela libertação da dominação de origem estrangeira; da mesma maneira, as mulheres afirmaram sua identidade contra a dominação de gênero. A história da liberdade no mundo moderno é a de uma associação cada vez mais estreita entre o universalismo dos direitos humanos e a particularidade das situações e relações sociais nas quais esses direitos devem ser protegidos. (Touraine, 1994, p. 263)

Touraine também não fala mais dos movimentos sociais como respostas negativas às estruturas de dominação, nem de suas ideologias como variações da cultura individualizante que as inspira.

Só existe movimento social quando a ação coletiva é dotada de objetivos sociais, quer dizer, reconhece a existência de valores e interesses sociais gerais e, em conseqüência, não reduz a vida política a um confronto entre campos ou classes, ainda que organize e acirre conflitos. Somente nas sociedades democráticas é que os movimentos sociais se formam sozinhos, pois a livre escolha política obriga cada ator social a lutar simultaneamente pelo bem comum e pela defesa de interesses particulares. Por essa razão, os movimentos sociais mais expressivos recorreram a temas universalistas: liberdade, igualdade, direitos do homem, justiça, solidariedade, temas que estabelecem um nexo direto entre o ator social e o programa político. (Touraine, 1994, p. 88)

Finalmente, no contexto do que se poderia chamar de "retour à démocratie" de Touraine, não surpreende que ele deseje restabelecer uma abordagem positiva e coletivamente unificada da sociedade civil em oposição a um enfoque negativo que realça o conflito.

A noção de movimento social aparece de modo ainda mais claramente associado à democracia e à defesa dos direitos humanos fundamentais quando confrontada com o conceito de luta de classes. [...] Os paladinos da luta de classes falam em contradições do capitalismo e em proletarização, e querem destruir o que destrói e negar a negação; esta é a base de demanda pela conquista do poder estatal. O movimento social, ao contrário, é civil, mais uma afirmação do que uma crítica e uma negação. (Touraine, 1994, p. 89)

Uma nova historicidade do contexto institucional e cultural dos movimentos sociais 
Para que se possa finalmente superar o modelo clássico dos movimentos sociais, é preciso acompanhar a abordagem do conflito que Touraine aplica à análise da ação, da cultura, das normas e das instituições, embora rejeitando energicamente o desconcertante historicismo que pelo menos até recentemente impedia esse grande pensador francês de dar o devido reconhecimento ao papel que as obrigações morais e políticas, e as instituições, desempenham na formação e regulação dos próprios conflitos. Isso porque o modelo clássico dos movimentos sociais não só fracassa na compreensão da especificidade das tentativas contemporâneas de realizar mudanças radicais; faz também uma descrição extremamente distorcida dos próprios movimentos revolucionários. A maioria das chamadas grandes revoluções inglesa, francesa, russa e chinesa teve como alvo anciens régimes, isto é, sociedades tradicionais em que o controle governamental dependia do hábito, dos costumes e do carisma, e, em épocas de crise, da repressão e da força. Nessas sociedades, a maioria do povo não tem acesso aos mecanismos de controle do Estado através da vigência das leis, da opinião pública ou da publicidade, muito menos dos mecanismos eleitorais. A alternativa à força como mecanismo de controle estatal é o poder legítimo que existe quando a obediência é mais voluntária do que resultado da coerção, quando a probidade é atribuída ao poder por razões morais em vez do hábito ou do medo. Essa possibilidade de construção da vontade, para usar a expressão de Habermas, só se dá quando existe uma esfera" civil" até certo ponto separada não só do Estado como também das outras esferas não-civis, religião, ciência, economia, família e comunidades básicas. E essa esfera civil independente só pode existir na medida em que se proteja a privacidade das interações individuais, garanta-se a independência das instituições para a criação de leis e para a formação da opinião pública, e que os padrões simbólicos normativos façam da honestidade, racionalidade, autonomia individual, cooperação e confiança impessoal critérios básicos para a participação na comunidade unificada que define a" sociedade".
O fato de que essas proteções civis apenas proporcionem direitos e oportunidades formais, não sua realização substantiva, não nega de maneira alguma a importância histórica da emergência da sociedade civil. Pois nas sociedades que transformaram as estruturas e culturas dos anciens régimes dessa forma, os movimentos sociais radicais que reivindicavam a redistribuição de recursos fundamentais não eram, na realidade, especialmente dependentes da força material, nem visavam exclusivamente à mobilização dos meios mais eficientes. Se esses movimentos nasceram, venceram ou fracassaram não foi simplesmente por uma questão de disponibilidade de redes e organizações, pois sua contestação não foi apenas instrumental; além disso, nem mesmo os movimentos mais radicais podiam ser entendidos como mobilizadores em face do poder do Estado como tal. Pelo contrário, ao menos desde o século XIX, e muitas vezes antes, os movimentos radicais surgiram das estruturas e códigos parcialmente conscientes das sociedades civis, de sistemas sociais em que a solidariedade civil estava fragmentada e a independência institucional das esferas não-civis fora sistematicamente deturpada. Para vencer, esses movimentos sociais tiveram de voltar-se não só para o Estado mas também para as instituições comunicativas, como a mídia, que mobilizam mais a persuasão do que a força, assim como para as instituições reguladoras, como a lei, destinadas, pelo menos em parte, muito mais a zelar pelo cumprimento das obrigações sociais e individuais de caráter universalista do que a favorecer o poder oligárquico. Como os movimentos sociais têm de seguir esse tipo de orientação, a questão da legitimidade torna-se preponderante. Diante de seus potenciais seguidores, os movimentos sociais nas sociedades civis têm de se apresentar como representantes típicos de determinados valores, como portadores do mito social, nacional e até primordial, como inovadores culturais capazes de criar novas normas e novas instituições que permitam canalizar recursos de uma maneira diferente. O poder desses movimentos não depende tanto dos dirigentes da organização e das redes de troca quanto do compromisso subjetivo com a lealdade e a solidariedade. Esses compromissos só podem ser estabelecidos quando os 
movimentos criam e sustentam novas formas de significado e novas identidades pessoais e grupais mais atraentes.

\section{Os movimentos sociais como traduções da} sociedade civil

Somente depois dessa revisão da historicidade do contexto cultural e institucional dos movimentos sociais dos séculos XVIII e XIX é possível elaborar uma alternativa coerente ao modelo clássico. A seção conclusiva deste ensaio será dedicada a traçar um esboço das principais linhas dessa alternativa.

Em todo sistema social relativamente desenvolvido há esferas diferenciadas que possuem regimes de valores peculiares, e muitos movimentos surgem e lutam no interior dessas esferas para obter justiça de modo descontínuo, pluralista e auto-regulador. 10 Entretanto, os mais expressivos idiomas, códigos e narrativas usados por movimentos sociais fortes, novos ou velhos, positivos ou negativos, independem de sua posição estrutural em esferas específicas. $\mathrm{Na}$ realidade, quando se examinam esses tropos, vê-se claramente que sua distância de arenas particulares é que confere influência aos movimentos, que lhes dá a possibilidade de evitar demandas institucionais imediatas e incentiva o exercício da ação em face das limitações institucionais implícitas na própria existência de um movimento social.

Essas estruturas simbólicas, de grande abrangência e transcendência, remetem à existência da sociedade civil, uma esfera separada de outros domínios institucionais, embora neles interfira. A "função" da sociedade civil não é produzir riqueza ou poder, salvação, amor ou verdade, mas criar e manter uma comunidade cujas fronteiras incluem esses domínios institucionais, que definem a "sociedade" como tal. Ser membro de uma sociedade civil é participar da ampla e inclusiva solidariedade do" individualismo institucionalizado" que proclama todos os homens e mulheres irmãos e irmãs, que cria deveres coletivos apesar de assegurar direitos individuais, e que provê a participação política na distribuição de bens sociais altamente valorizados. Não é fácil tornar-se membro dessa comunidade, e a verdade é que essa participação sempre foi obstinadamente contestada.

Embora a participação numa sociedade civil seja altamente contingente, as categorias de atributos que a legitimam ou negam não o são. Os membros efetivos, ou os aspirantes a membros, justificam e impedem a participação por meio de pares de oposições simbólicas que têm permanecido extraordinariamente constantes durante um longo período de tempo. Há um discurso característico que define o núcleo cultural das sociedades civis e proporciona as metalinguagens adotadas pelos que aspiram participar dela (ver, por exemplo, Alexander e Smith, 1993; Sherwood, 1994; Smith, 1994). Sua estrutura compõe-se de antinomias que definem atributos positivos muito valorizados e atributos negativos de elevada impureza. Juntas, essas antinomias definem motivações, relações e instituições legitimadoras da inclusão e exclusão social. Independência/dependência,

racionalidade/irracionalidade, honesto/desonesto, crítico/ingênuo, são exemplos das categorias morais que definem possibilidades motivacionais. Confiante/desconfiado, respeitoso/injurioso, prestativo/hostil, manifesto/secreto indicam tipos de pares de relações alternativas. Público/privado, participativo/autoritário, flexível/rígido referem-se a possibilidades institucionais que definem alternativas importantes em si mesmas e relações de motivação homóloga. Essas relações binárias, de alto grau de intertextualidade, definem atributos extremamente simplificados de bom e mau, vistos como "essências" que separam o puro do impuro, amigos de inimigos, o sagrado do profano. Códigos impuros definem uma identidade que merece repressão, ao passo que códigos puros constroem os candidatos ao exercício desta tarefa.

Visto que esse discurso da sociedade civil institucionalizouse em épocas diferentes e de maneiras distintas, parece importante assinalar que, em termos históricos, ele se 
estende muito além das "historicidades" um tanto estreitas e economicamente delimitadas definidas por Touraine e pela teoria dos novos movimentos sociais. $\frac{11}{}$ A noção de uma esfera civil abrangente e democrática tem influenciado o pensamento ocidental há séculos. O desenvolvimento embrionário e desigual de instituições comunicativas e reguladoras certamente pode ser encontrado em várias regiões da Europa nos séculos XIII e XIV, nas aldeias inglesas, nas cidades-estados da Itália e da Alemanha, nas instituições igualitárias dos parlamentos aristocráticos que elegiam reis. $\frac{12}{}$ Elementos do discurso da sociedade civil inspiraram as grandes insurreições religiosas e culturais, como a Reforma e o Renascimento, assim como as instituições econômicas do capitalismo de mercado, os novos Estados racionalizados e as revoluções democráticas nascentes. Diferentes combinações de elementos institucionais e culturais da sociedade civil podem ser observados nas corporações artesanais, ou guildas, e em comunidades agrícolas independentes, nas economias mercantilistas, nos períodos industrial e pós-industrial, em sociedades religiosas e seculares, em formações sociais prénacionais e em Estados nacionais. No entanto, uma concepção forte e coerente de sociedade civil, como uma comunidade imaginária inspirada pelas dicotomias culturais acima mencionadas e organizadas por instituições comunicativas e reguladoras, somente apareceu no final do século XVII. Só depois que surgiu uma sociedade civil parcialmente independente é que os movimentos sociais emergiram como fenômenos importantes e organizados, e tornou-se possível, pela primeira vez, uma mudança social organizada.

Os movimentos sociais alimentam-se de um senso de comunidade total. Embora os próprios movimentos constituam apenas um grupo específico, alegam ou (a) "representar" a sociedade como um todo, seus desejos e seus melhores interesses (por exemplo, um grupo de defesa do meio ambiente ou da cidadania), ou (b) falar diretamente à" sociedade" em nome de um interesse particular (por exemplo, um sindicato, ou um grupo de defesa dos afroamericanos ou das mulheres). Portanto, os movimentos sociais não podem ser considerados como simples respostas aos problemas existentes; por exemplo, às tensões inerentes a um determinado tipo de economia, Estado, geografia, legalidade, tipo de família ou campo científico; ao contrário, devem ser entendidos como respostas à possibilidade de construir "problemas" convincentes nesta ou naquela esfera, e de transmitir essa "realidade" ao conjunto da sociedade. Antes de formar-se um movimento social, seja um movimento operário, seja um movimento pela libertação das mulheres, poucos atores reconhecem a existência do problema que é colocado pelo movimento, muito menos que haja uma solução para ele. O que legitima a construção do movimento na realidade, sua principal motivação é a referência latente às obrigações criadas pela sociedade civil.

Quando se examina a retórica dos movimentos sociais, vêse que a imagem de um" debate franco e imparcial", de "nossa data marcada de julgamento", da" sociedade" como uma representação ética e moral solidária, parece estar sempre presente. Por trás dos movimentos sociais sempre está a referência a uma comunidade extremamente idealizada que exige, como diz Hegel, que o universal se torne concreto. Essa demanda por um universal concreto aparece sobre o pano de fundo de uma noção utópica de comunidade de acordo com a qual os atores racionais forjam espontaneamente vínculos ao mesmo tempo autoreguladores, solidários e emancipadores, independentes das recompensas do mercado, da fé religiosa, do afeto familiar, da coerção do Estado e da verdade científica. Touraine fala da comunidade que se regula e se constitui por si mesma como uma realidade iminente na sociedade pós-industrial, mostrando-a como prova de que nada restou da "sociedade" como tal. No entanto, é evidente que a própria linguagem dos movimentos sociais contemporâneos sugere que essa não é bem a verdade. Comunidades que se constituem por si mesmas não são realidades, mas ideais reguladores que inspiram tanto a metalinguagem dos movimentos" progressistas" quanto "retrógrados" não só da atualidade como do passado.

A existência desse ideal regulador, e até mesmo sua concretização parcial nas instituições comunicativas e reguladoras de um período histórico determinado, é que 
permite a transferência de protestos gerados em um setor estrutural para a esfera da sociedade civil. Os problemas não dizem mais respeito a uma instituição específica, mas à própria sociedade, e têm a potencialidade de provocar uma "crise social". A ação coletiva pode ser entendida como uma luta por posições ante os antagonismos das categorias da vida civil, como uma luta para representar outros atores definidos por categorias negativas e impuras e para representar a si mesmo como sagrado. Passar de um problema relativo a uma esfera específica da sociedade a um problema da sociedade toda exige que os líderes dos movimentos sociais ajam com criatividade e imaginação. É o que se poderia chamar de problema da "tradução", no qual a criatividade cultural e a competência política são igualmente importantes. Usar uma organização com eficiência é muito diferente de simplesmente recrutar membros, instalar linhas telefônicas e levantar fundos; significa aprender a traduzir experiências, do particular para o geral, do institucional para o civil e vice-versa. Os intelectuais do movimento muitas vezes concebem suas tarefas em outros termos; considerando os problemas do movimento como reais, vêem a tradução do particular para o geral como algo que "já está sempre lá", fincado na materialidade do problema em si. A ambição de um movimento social deve ser, porém, a de recolocar demandas específicas, tirá-las de instituições particulares para o interior da própria sociedade civil. Quando os "intelectuais do movimento" (Eyerman e Jamison, 1991) são bem-sucedidos nessa tarefa, os movimentos "iniciam uma conversação" com a sociedade e atraem a atenção dos seus membros para uma compreensão mais global de sua causa. $\underline{13}$ Quando isso acontece, o problema e o grupo que o aciona entram definitivamente na vida pública.

A tradução bem-sucedida carrega os movimentos originários de protestos iniciados em um setor da estrutura um subsistema diferenciado, uma esfera da justiça, um regime de justificação para a órbita da "sociedade como um todo"; permite a costura de alianças, a formação de alinhamentos de massa e a organização da propaganda. A dominação numa esfera particular é contestada não por infringir a cultura institucional que define a historicidade, mas porque foi construída a partir da violação das representações coletivas da sociedade civil. Dessa maneira, os poderes dominantes podem ser representados pelas mesmas categorias de exclusão que adotaram anteriormente para legitimar a exclusão de outros atores. $\mathrm{Na}$ dinâmica desse processo inverso de estigmatização, estruturas narrativas arquetípicas entram em cena para exaltar a imagem dos desafiadores e diminuir a dos poderosos. De personagens solitários e oprimidos, os líderes dos movimentos e organizações são transformados em figuras heróicas que se aventuram numa busca romântica. Lances melodramáticos tingem o movimento e seus opositores de branco e preto, e o conflito é retratado em tons sentimentais, muitas vezes moralistas e simplistas. Recursos cômicos, como a ironia e a comédia, são adotados para reduzir ainda mais a importância de identidades agora vistas como impuras.

Capitalistas e operários não travaram uma luta secular apenas para defender interesses materiais antagônicos, ainda que se leve em conta os efeitos interpretativos da cultura industrial. Ao contrário, as tensões econômicas traduziram-se em categorias da esfera civil (cf. Pizzorno, 1978). Destruição de máquinas, demandas salariais, greves e campanhas de sindicalização foram conduzidas em termos "dos direitos dos ingleses". O status de operário foi exaltado e ele se tornou emblemático da condição humana. Agora os operários se sentiam autorizados a exigir pleno acesso às instituições reguladoras, como a lei e os tribunais, responsáveis por decisões vitais na distribuição dos meios. Com a ajuda dos movimentos sociais, os operários" broncos", "cobertos de fuligem", os homens sujos, dependentes, violentos e turrões, dos quais se dizia que trabalhavam com as mãos e não com a cabeça, conseguiram reconstruir sua própria imagem e do seu grupo em termos menos impuros e mais sagrados. Muitas vezes conseguiram inclusive inverter a categoria de identificação dos proprietários, classificando-os como dissimulados em seus motivos, dependentes em suas relações e autoritários em suas instituições.

A emancipação religiosa não teve um efeito muito diferente. Desde a Idade Média, surgiram movimentos de 
protesto contra a hierarquia eclesiástica e a favor de direitos mais inclusivos considerados inseparáveis da esfera civil. Da mesma maneira, as mulheres começaram pouco a pouco a rejeitar sua identificação com os papéis domésticos e maternos definidos pelo patriarcalismo. Como os judeus isolados em guetos, os protestantes reprimidos ou os operários manuais explorados, as mulheres começaram a se dar conta de sua dupla participação, não só como membros de uma estrutura familiar em que lealdade, amor e respeito são critérios básicos, mas como membros da sociedade civil, na qual se exigia crítica, respeito e igualdade. Nos movimentos estudantis dos anos 60, os estudantes rejeitavam a subordinação na escola, na família e no trabalho, afirmando, de maneira semelhante, que nem a autoridade paterna, nem a autoridade baseada no saber justificavam a subordinação e a objetificação a que estavam sujeitos na escola e na família. Formando comunidades próprias de forte solidariedade moral e emocional, exigiam que a sociedade os tratasse na sua condição de cidadãos. Movimentos de defesa dos consumidores e dos direitos dos pacientes também podem ser considerados como manifestações de dupla participação, pois as tensões entre a sociedade civil e as esferas econômica e profissional criam pressões para que se redefinam os limites onde terminam as obrigações civis e começam os interesses mais especializados. Minorias étnicas e raciais dominadas recorrem à sua dupla participação para reivindicar a assimilação ou legitimação do multiculturalismo. No caso das pessoas portadoras de deficiência física ou mental, para quem categorias que conotam impureza, como irracionalidade, insanidade e dependência, muitas vezes assumem um essencialismo que se expressa no corpo, o processo de tradução é muito difícil, e só recentemente começamos a redefinir o significado desses atributos físicos. No caso do movimento ecologista, por exemplo, a própria natureza é redefinida. Se em outros tempos esta foi vista como sangrenta, hoje é uma parceira potencialmente racional e cooperativa, aceita plenamente como membro nas sociedades civis.

Os movimentos sociais podem ser vistos como mecanismos sociais que constroem traduções entre o discurso da sociedade civil e os processos institucionais específicos de tipo mais particularista. São movimentos de natureza prática e histórica, mas que apenas podem ter êxito se forem capazes de empregar a metalinguagem civil para relacionar esses problemas práticos ao centro simbólico da sociedade e suas premissas utópicas. Estamos agora muito longe do modelo clássico dos movimentos sociais, com seu realismo, materialismo e preocupação exclusiva com a derrubada do poder prático do Estado. Contudo, estamos também muito longe da teoria dos novos movimentos sociais, que trata os argumentos simbólicos como estratégias de defesa contra o isolamento e a vulnerabilidade de atores que se defrontam com novas formas de dominação técnica. Vimos que, numa parte do seu argumento, Touraine sugere um ponto de vista muito diferente. Designa os movimentos sociais como respostas idealizadas à tensão entre orientações culturais utópicas e gerais e a posição institucional limitada que caracteriza a contestação na vida cotidiana. A única maneira de desenvolver essa idéia seminal é relacionar os movimentos sociais à cultura e às estruturas da sociedade civil.

A política é uma luta discursiva; trata da distribuição de líderes e seguidores, grupos e instituições, ao longo de conjuntos simbólicos altamente estruturados. Conflitos de poder não se referem apenas a quem leva o que e quanto; dizem respeito também a quem será o que e por quanto tempo. Se na ação recíproca entre instituições comunicativas e seu público um grupo é representado a partir de um ou outro conjunto de categorias simbólicas é um fato absolutamente decisivo; muitas vezes, chega a tornar-se uma questão de vida ou morte. No decurso de conflitos sociais, indivíduos, organizações e grandes grupos podem ser transferidos de um lado para o outro da classificação social, através de súbitas e muitas vezes desnorteantes rupturas do tempo histórico. Todavia, por mais inovadoras que pareçam ser, essas categorias são variações de temas muito antigos e consolidados. 


\section{NOTAS}

1 "A ‘revolução' tem uma vida dupla, de duas caras. De um lado, pertence ao discurso societário, ao pensamento de senso comum, como o que se poderia chamar de mito da revolução. De outro, pertence a um discurso sociológico, surgindo como um raciocínio científico sobre a teoria da revolução. [...] A teoria da revolução baseia-se muito no mito da revolução; com um inevitável atraso temporal, explica e sistematiza o que o homem comum pensa sobre a revolução." (Sztompka, 1990, pp. 129-130).

2 Recente discussão sobre as revoluções, que sublinha exatamente esses atributos, encontra-se em Sztompka (1993, especialmente pp. 259-273 e 301-321).

$\underline{3}$ Elihu Katz recentemente relembrou os aspectos da obra de Tarde que se relacionam com seus próprios estudos sobre o impacto das organizações secundárias, de mediação, diante dos meios de comunicação de massa.

4 Ver a importante crítica do" situacionismo social" anticultural de Campbell (1996).

5 De acordo com o argumento de Eyerman e Jamison de que, para a maioria dos sociólogos americanos que estudam os movimentos sociais, o "saber cultural se torna desincorporado; é relegado a um nível em grande parte marginal, efêmero ou superestrutural da realidade, e não ao centro do movimento de formação de identidades ao qual [...] pertence. [...] O interesse de um movimento social no conhecimento congela-se em pacotes estáticos, prontos, que fornecem as questões ou ideologias que concentram a mobilização de recursos ou a socialização dos indivíduos.

[...] Uma das principais barreiras ao reconhecimento dos movimentos sociais como produtores de conhecimento é a tendência geral de reificá-los, identificá-los com organizações, partidos, seitas, instituições." (Eyerman e Jamison, 1991, pp. 46 e 59).

6 Essa crítica do pensamento marxista tradicional assemelha-se muito à de Gramsci, cuja obra deve ter influenciado Touraine de maneira profunda, embora ele não o admita. De fato, dentre os intelectuais mais importantes da tradição revolucionária, Gramsci foi o único que conseguiu evitar os erros do modelo clássico. A contestação revolucionária dos operários industriais haveria de vencer, diz Gramsci, não pelo exercício eficaz da força ou mesmo da ameaça de fazer uso dela, mas pela conquista do controle hegemônico das estruturas culturais dentro das quais são interpretados os conflitos materiais. Gramsci entendeu que as instituições comunicativas da sociedade civil, não os organismos de coerção do Estado, é que devem ser os alvos da luta. Era preciso persuadir os potenciais cidadãos de que as idéias comunistas ofereciam uma visão intelectualmente mais coerente e moralmente mais irresistível da boa vida.

7 Esse movimento lembra a famosa advertência de Habermas (1987, p. 199) aos teóricos de esquerda mais ou menos na mesma época: "Nenhuma teoria da sociedade pode ser hoje em dia levada a sério se no mínimo não se posicionar em relação a Parsons. Enganar-se a esse respeito é permanecer preso a questões tópicas em vez de ser sensível a elas."

8 A análise mais lúcida de Touraine a respeito desses movimentos encontra-se em L'après socialisme (1980, pp. 141-171).

9 Melucci faz exatamente a mesma observação de que a sociedade civil é um produto dos movimentos sociais contemporâneos.

10 Walzer (1984) e Boltanski e Thevenot (1990) contêm a mais importante análise dessas esferas específicas.

11 Cf. Cohen e Arato (1992, pp. 493-494): "Não acreditamos que seja possível justificar essa afirmação sobre o que é novo nos movimentos a partir de uma filosofia da história que associa a 'verdadeira essência' do que 'realmente são' os movimentos sociais (por mais heterogêneas que sejam suas práticas e formas de consciência) a uma pretensa nova etapa da história (sociedade pós-industrial). Tampouco o tema da `sociedade contra o Estado', partilhado por todos os movimentos 
contemporâneos [...] implica em si mesmo algo novo no sentido de uma ruptura radical com o passado. Ao contrário, o tema implica uma continuidade com o que merece ser preservado [...] nas instituições, normas e culturas políticas das sociedades civis contemporâneas."

$\underline{12} \mathrm{O}$ estudo recente de Somers sobre a revolução jurídica na Inglaterra medieval revela que o tema da cidadania comum já impregnava determinadas sociedades nos séculos XV e XVI. Ver também o conceito de Weber de racionalização, fraternização e cidades-estados.

13 "Pela expressão movimento intelectual referimo-nos aos indivíduos que através de suas atividades articulam os interesses no saber e a identidade cognitiva dos movimentos sociais" (Eyerman e Jamison, 1991, p. 98).

\section{BIBLIOGRAFIA}

ALEXANDER, J.C. (1995), "Modern, ante, post, and neo: how intellectuals have coded, narrated, and explained the 'crisis of our times"', in J.C.Alexander, Fin-de-siècle social theory: relativism, reduction, and the problem of reason, Londres, Verso.

ALEXANDER, J.C. e COLOMY, P. (1988), "Social differentiation and collective action", in J.C. Alexander, Action and its environment, Nova York, Columbia University Press, pp. 193-221.

ALEXANDER, J.C. e SMITH, P. (1993), "The discourse of American civil society: a new proposal for cultural studies". Theory and Society, 22: 151-207.

BAKER, K. (1990), Inventing the French Revolution. Nova York, Cambridge University Press.

BLUMER, H. (1951) [1939], "Collective behavior", in A.M.Lee (ed.), Principles of Sociology, Nova York, Barnes e Noble, pp. 165-222.
BOLTANSKI, L. e THEVENOT, L. (1990), De la justification. Paris, PUF.

BRANCH, T. (1988), Parting the waters: American in the king years: 1954-1963. Nova York, Simon e Schuster.

CAMPBELL, C. (1996), Social situationism. Cambridge, Cambridge University Press.

COHEN, J. e ARATO, A. (1992), Civil society and political theory. Cambridge, Mass., MIT Press.

COOLEY, W.H. (1909), Social organization. Nova York, Charles Scribner.

DEWEY, J. (1927), The public and its problems. Nova York, H. Holt.

ENGELS, F. (1889), "Preface", in Karl Marx, O Capital III, Moscou, International Publishers.

EYERMAN, R. e JAMISON, A. (1991), Social movements: $a$ cognitive approach. Cambridge, Polity Press.

FRIEDMAN, D. e McADAM, D. (1992), "Collective identity and activism: networks, choices, and the life of a social movement", in A.D.Morris e C.M.Mueller (eds.), Frontiers in social movement theory, New Haven, Yale University Press, pp. 156-73.

FURET, F. (1981) [1978], Interpreting the French Revolution. Nova York, Cambridge University Press.

GAMSON, W.A. (1988), "Political discourse and collective action". International Social Movement Research, 1: 219-244.

(1992), "The social psychology of collective action", in A.D. Morris e C.M. Mueller (eds.), Frontiers in social movement theory, New Haven, Yale University Press, pp. 53-76.

GIDDINGS, F.H. (1896), The scientific study of human society. Chapel, University of North Carolina Press. 
HABERMAS, J. (1987), Theory of communicative action. vol. II: Lifeworld and system: a critique of functionalist reason. Boston, Beacon.

HUNT, L. (1984), Politics, culture, and class in the French Revolution. Berkeley, University of California Press.

(ed.). (1989), The new cultural history. Berkeley,

University of California Press.

JOYCE, P. (1991), Visions of the people: industrial England and the question of class. Nova York.

KLANDERMANS, B. (1988), "The formation and mobilization of consensus", in H.P.Klandermans e S.Tarrow (eds.),From structure to action: comparing movement participation across cultures, Greenwich, JAI Press.

(1992), "The social construction of protest and multiorganizational fields", in A.D. Morris e C.M. Mueller (eds.), Frontiers in social movement theory, New Haven, Yale University Press, pp. 77-103.

LASSWELL, H. (1941), Democracy through public opinion. Menasha, WI, George Banta.

LIPPMAN, W. (1992), Public opinion. Nova York, Harcourt Brace.

McADAM, D. (1988), Freedom summer. Nova York, Oxford University Press.

McCARTHY, J.D. e ZALD, M.N. (1977), "Resource mobilization and social movements: a partial theory". American Journal of Sociology, 82, 6: 1.212-1.241.

MANN, M. (1986), The origins of social power, I. Cambridge, Cambridge University Press.

(1994), The origins of social power, II.

Cambridge, Cambridge University Press.
MARX, K. (1962a) [1875], "Critique of the Gotha programme", in Marx and Engels: Selected Works II, Nova York, Foreign Languages Publishing House.

(1962b) [1867], Capital, vol I. Moscou, International Publishers.

(1963) [1844], Economic and philosophical manuscripts. Nova York, Foreign Languages Publishing House.

(1967) [1845], The boly family. Nova York, Foreign Languages Publishing House.

(1970) [1846], The german ideology. Moscou, International Publishers.

MARX, K. e ENGELS, F. (1972) [1848-49], The revolution of 1848-49. Editado por Bernard Isaacs. Moscou, International Publishers.

MEAD, G.H. (1964), Mind, self and society. Chicago, Chicago University Press.

MELUCCI, A. (1980), "The new social movements: a theoretical approach". Social Science Information, 19, 2: 199226.

(1989), "Social movements and the democratization of everyday life", in John Keane (ed.), Civil society and the state, Londres, Verso, pp. 245-260.

(1992), "Liberation or meaning? Social movements, culture and democracy". Development and change, 23, 3: 43-77.

MONTGOMERY, D. (1980), "Labor and the republic in industrial America: 1860-1920". Le Movement Social, 111: 201-215.

MORRIS, A. (1984), The origins of the civil rights movement. Nova York, Free Press. 
OBERSCHALL, A. (1973), Social conflicts and social movements. Englewood Cliffs, Prentice-Hall.

PARK, R.E. (1972) [1904], The crowd and public and other essays. Chicago, University of Chicago Press.

PARSONS, T. e SHILS, E. (1951), "Values, motives, and systems of action", in T. Parsons e E. Shils (eds.),Towards a general theory of action, Cambridge, Cambridge University Press.

PIZZORNO, A. (1978), "Political exchange and collective identity in industrial conflict", in C.Crouch e A.Pizzorno (eds.), The resurgence of class conflict in Western Europe since 1969, vol. 2, Londres, Macmillan, pp. 277-298.

SEWELL JR., W. (1980), Work and revolution in France: the language of labor from the old regime to 1848. Nova York, Cambridge University Press.

. (1985), "Ideologies and social revolutions: reflections on the French case". Journal of Modern History, 57: 570-585.

SHERWOOD, S.J. (1994), "Narrating the social: postmodernism and the drama of democracy". Journal of Narrative and Life History, 4, 1/2: 69-88.

SKOCPOL, T. (1979), States and social revolutions. Cambridge, Harvard University Press.

SMALL, A.W. e VINCENT , G.D. (1894), An introduction to the study of society. Nova York, American Book Company.

SMELSER, N.J. (1962), Theory of collective behavior. Nova York, Free Press.

SMITH, P. (1994), "The semiotic foundations of media narratives: Saddam and Nasser in the American mass media". Journal of Narrative and Life History, 4, 1/2: 89-118.

SNOW, D.A. e BENFORD, R.D. (1988), "Ideology, frame resonance, and participation mobilization". International Social Movement Research, 1: 197-217.
SNOW, D.A., BURKE ROCHFORD JR., E., WORDEN, S.K. e BENFORD, R.D. (1986), "Frame alignment process, micromobilization, and movement participation". American Sociological Review, 51: 464-481.

SWIDLER, A. (1986), "Culture in action: symbols and strategies". American Sociological Review, 51: 273-286.

(1996), "Cultural power and social movements", in H. Johnson e B. Klandermans (eds.), Culture and social movements, Minneapolis, University of Minnesota Press.

SZTOMPKA, P. (1990), "Agency and revolution". International Sociology, 5, 2: 129-144. . (1993), The sociology of social change. Oxford, Blackwell.

TARROW, S. (1992), "Mentalities, political cultures, and collective action frames: constructing meaning through action", in A.D. Morris e C.M. Mueller (eds.), Frontiers in social movement theory, New Haven, Yale University Press, pp. 174-202.

(1994), Power in movement: social movements, collective action and politics. Cambridge, Cambridge University Press.

THOMPSON, E.P. (1964), The making of the English working class. Harmondsworth, Penguin.

TILLY, C., TILLY, L. e TILLY, R. (1975), The rebellious century, 1830-1930. Cambridge, Harvard University Press.

TOURAINE, A. (1977), The self-reproduction of society. Chicago, University of Chicago Press. . (1978), Lutte étudiante. Paris, Seuil. . (1980), L'après socialisme. Paris, Seuil. (1981), The voice and the eye: an analysis of social movements. Cambridge, Cambridge University Press. 
(1983a), "Triumph or downfall of civil society?". Humanities in Review, 1: 218-234.

(1983b), Anti-nuclear protest: the opposition to

nuclear energy in France. Cambridge, Cambridge University Press.

(1984), "The waning sociological image of social life". International Journal of Comparative Sociology, 25, 1 2: $33-44$.

(1985), "Social movements, revolution, and democracy", in R. Schurmann (ed.), The public realm: essays on discursive types in political philosophy, Buffalo, State University of New York Press, pp. 268-283.

(1988), Return to the actor. Minneapolis, University of Minnesota Press. . (1992a), "Beyond social movements". Theory,

Culture, and Society, 9: 125-145.

. (1992b), Critique de la modernité. Paris, Fayad.

(1994), Qu'est-ce que la democratie? Paris, Fayad.

TOURAINE, A. e DUBET, F. (1981), Le pays contre l'Etat.

Paris, Seuil.

TOURAINE, A., WIEVIORKA, M. e DUBET, F. (1987), The workers' movement. Cambridge, Cambridge University Press.

TUCKER JR., K.H. (1996), Public discourse and the fate of labor: an analysis of revolutionary syndicalism in France. Nova York, Cambridge University Press.

TURNER, R. e KILLIAN, L. (1972), Collective behavior. Englewood Cliffs, Prentice-Hall.

WALZER, M. (1984), Spheres of justice. Cambridge, Harvard University Press.
WILENTZ, S. (1984), Chants democratic: New York City and the rise of the American working class. Nova York.

* Tema discutido pelo autor na Conferência "A sociedade civil entre a diferença e a solidariedade", proferida no XXI Encontro anual da Anpocs, Caxambu, outubro de 1997.

** Gostaria de manifestar minha gratidão a Roger Friedland por sua contribuição na elaboração deste ensaio. Seus trabalhos não publicados sobre a teoria dos movimentos sociais, bem como suas críticas e sugestões, mostraram-me o caminho de muitos argumentos contidos neste ensaio. Agradeço também às valiosas críticas dos integrantes do UCLA Culture Club.

Tradução de Vera Pereira.

Revisão técnica de José Maurício Domingues. 